\title{
Proceedings of the 21st Symposium on Laboratory Animals
}

(Tokyo, February $7 \& 8,1974$ )

\begin{abstract}
A. Infections with Corynebocterium kutscheri and Sendai Virus in mouse and rat colonies.
B. Roles of monkeys in animal experiments as models for human beings.
\end{abstract}

第21回実験動物シンポジウム記録

(1974年 2 月 $7 \cdot 8$ 日)

\section{第 1 日 2 月 7 日（木）}

I・あいさつ

理事長 田 嶋 嘉 雄 $(9: 00 \sim 9: 15)$

II. シンポジウム

A．マウス・ラットコロニーにおけるネズミコリネ菌 (Corynebacterium kutscheri)

およびセンダイウイルス $(\mathrm{HVJ})$ の污染

$(9: 15 \sim 14: 45)$

はじめに

藤 原 公 策 (東大·医科研)

第 1 部 皂ズミコリネ菌污染
1. 病型の多様性
$\bigcirc$ 二木 力 夫 高 坦 善 男 (中外製薬·綜合研)
2. 潰愓性大腸炎
○山田明甫·小河 秀 正 (第一製薬. 中央研)
3. 経口感染の成立条件
横井山 繁 行 (東洋醸造)
4. コーチゾン処置・蛍光抗体法による污染チェック

5. 血清抗体による污染チェック

内 海 健二朗 (大日本製薬)

松 沼 尚 史 (三共. 中央研)

第 2 部 センダイウイルス
1. 病変と病型
武藤健（国立予研）
2. 重複感染
中川雅 郎 (国立予研)
3. ウイルス伝播
飯田毅 (三共·中央研)
4. マウス生産コロニーの污染
藤 原 公 策 (東大·医科研)
5. ラット生産コロニーの污染
牧 野

$(12: 30 \sim 14: 45)$

B. ヒトのモデルとしてのサル類の有効性とその限界
はじめに
本庄重 男 (国立予研)
田中利男(日本モンキーセンター)

第 1 部 サルをモデルとして使っている立場から

$$
\begin{aligned}
\text { 座 長 柳 } \text { 田 知 司 (実中研) } \quad(15: 00 \sim 16: 20) \\
\text { 中 田 } \\
\text { 大 利 男 (日本モンキーセンター) }
\end{aligned}
$$

1. 内分泌と代謝

2. 毒性実験に打けるサル類の有効性と限界

$$
\begin{aligned}
\text { 松 島 松 翠·阿 部 栄四郎 (日本農村医学研) } & \\
& \text { 坐 長 小 川 次 郎 (名古屋市大·医) } \quad(16: 20 \sim 19: 00)
\end{aligned}
$$

田中利男 (日本モンキーセンター)
3. ウイルス感染
山内 一也（国立予研）
4. 歯科の領域
五. 嶋 秀 男 (城西歯大)

5. 新生児学の基礎としてのサル類での実験的研究の現況

6. 栄養と発育

杉 浦 寿 康 (名古屋市大·医)

皇山富 而 (岩手医大·医) 


\section{第 2 日 2 月 8 日 (金)}

B. ヒトのモデルとしてのサル類の有効性とその限界（つづき）

第 1 部 サルをモデルとして使っている立場から

$$
\text { 座 長 柳 田 知 司 (実中研) (9:30 10:50) }
$$

7. 神経生理の立場から

田中利男 (日本モンキーセンター)

7. 心理 · 行動

真 野 範 一(都・神経科学総合研)

第 2 部 自然保護, 飼育・生産管理の立場加ら 糸魚川 直 祐 (阪大·人間科学部)

$$
\begin{aligned}
\text { 座 長 猪 } & \text { 貴 義 (岡山大·農) } \\
& \text { 本 庄 重 男 (国立予研) }
\end{aligned}
$$

1. 野生ザルの保護と利用水 原 洋 城 (日本モンキーセンター)

2. “ノーマルデーター”および自然発生の疾病

和 秀 雄 (日本モンキーセンター)

3. 野生環境から実験室への順応および温熱性代謝性反応からみた飼育管理

登 倉 尋 実 (京大·霊長研)

大 野 拓 $夫$ (名大·農)

座長 中 井斌 (放医研)

4. 生産の必要性と方法

本庄 重 男 (国立予研)

5. 入手，実験に際して特に注意すべき諸点 長文 昭（国立予研） 第 3 部 総合討論 座 長 本庄重 男 (国立予研) 田中利男 (日本モンキーセンター)

\section{あい \\ 理事長 田}

恒例の実験動物談話会が開かれるととになりました。 “特定のテーマをえらんであたれる話しあいの場” とし ての談話会む, 会を重ねるとと21回になりました。今年

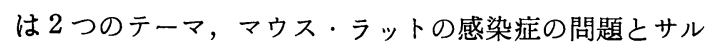
類がえらばれ，それぞれ特徴のあるとりあげ方がされて おります。その点について，司会者の企画の言葉がそれ ぞれ添えられるでありましょうが，会長として，あいさ つがわりにひとことふれさせていただきます。

\section{マウス・ラットの感染症の問題}

前回 (第20回) の談話会で SPF 動物がテーマのひと つとしてとりあげられました。その話しあいの場での結 論のひとつに, 実験動物の感染症対策としては, 個々の 感染症について, 污染の実状分析を詳細に行なうことか ら出発して病気の全体を整理することがまず必要であろ う, ということがありました。今回, 感染症がテーマに えらばれたことは，それに対する回答であり，2つの微 生物にしぼられたことは, じゅう分に解析したいとする 企画者の意図のあらわれでありましょう。

なお，他の感染症につきましては，つぎの機会にとり

\section{さ っ}

嶋嘉雄

あげられるととと存じます。

サル類の問題

実験用サルについては第15回談話会（1968年）でとり あげられ，供給の立場と動物実験の立場から問題点が提 示され，討議が行なわれました。以来 6 年，サル類の供 給・使用の分野にもいろいろな変遷がみられておりま す。そこに，あらためてサル類をとりあげる意義があり ましょう。

ととろで, 今回のテーマに“有効性とその限界”とい う言葉がつかわれて抢ります。との言葉はすべての実験 用動物にあてはめられるあのであり，ての言葉で表現さ れる内容を具体的に理解するここは大変重要でありま す。そして，サル類については，それのヒトとの類似性 が他の動物種とくらべてきわだって大きいとされている ことからみて, その言葉の内容を正しく理解することは とくに重要であるといえましょう。今回提示されるのは 限られた範囲のととでありましょうが，これを機会に， より広くより深く, サル類の有効性（有用性）とその限 界を理解する方向にすすみたいと願うあのであります。

実り多い談話会となるととを祈ります。 


\section{シンポジウムA. \\ マウスラットコロニーにおけるネズミコリネ菌 Corynebacterium kutscheri およびセンダイウイルス $(\mathrm{HVJ})$ の污染}

司会のことば

藤 原 公 策 (東大医科研)
中 川 雅 郎 (予研)

実験の成績や生産効率に影響する実験動物の病気, と くに感染病をどうコントロールするかについては, 研究 会の発足当初から多大の関心が寄せられ，とくに近年 barrier system の普及をはじめとしてかなりの成果む 挙げられてはいる。しかし，一方では，あっとも多用さ れるマウスラットについてさえ, どのような病気を対象 とし，どのような検查手段によって污染をしらべるか， を指示する基準らしいあのも未だに設定されていない。 このととは実験動物の病気にとくに関係の深い私どもの 層の薄さ，力の足りなさにあよるが，一面ではやはり， 今日のように, 長期毒性試験などに関連して, 感染病污 染の排除がいかに重要であるかが強く認識されてくるの を待たねばならなかったように思える。何故ならば，今 日では，いうところの重要な感染因子の種類あ，また， 動物コロニーの環境屯, 古くから教科書的に記述されて いるものとは大きく異なっている。したがって污染の検 查方法を確立し，対策をたてるためには，今日的な実験 動物コロニーに，それぞれの感染因子がどのような経路 で侵入し, どの程度の被害をむたらすかについて，ある 程度の経験をつむ必要があったからである。

つぎに，何故センダイウイルスとネズミコリネ菌をと りあげたかについてお断わりしておきたい。これまでに あ実験動物，とくにマウス，ラットの感染病の全般につ いては，しばしば議論をする機会があたれながら，いつ あ総論的な扱加い終始するととが多く，いわゆる SPF なる言葉がこれほどひろく使われるようになったにあか かわらず，何をむってマウス，ラットの重要感染病とす るのか，についての一致した見解がしめされていない。 そこで今回はこれまでの総論的なとりあげかたをくり返 すことなく，各論に徹して，1，2 の感染症のみを，時 間のゆるすかぎり名指しで論じてみようということにな

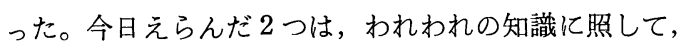
マウス, ラットの感染として決してはずすてとのできな い，細菌およびウイルス感染であって，できれば今日の 話題提供と議論を通じて検查規準の確立へともってゆき
たい。もちろん別の機会には他の感染病についても，て ういった “公聴会”的な議論の場を重ねて基準の設定へ 方向づけたいと思っている。

以上述べた背景を基礎に各演者に話題の提供をお願い したが，一方では，污染の観察とその検出についての貴 重な経験にもとづいた話題の提供がなされるはずであ り，また，いま一方では，污染の検出方法や対策を考え るために必要な, 各病原因子の生物学的性状, 感染経 路, 動物の感受性についての実験感染病学的解析につい て話題が提供されよう。いずれの立場からであるとを問 わず，その感染病の実験動物コロニーに拉けるコントロ ールについて具体的な提言を最後にひとととつけ加えて いただくよう各演者に打願いしてあるので，抒聞き落し のないよう御静聴いただき, 先に触れたように, 検査基 準設定のために有益な議論が展開されるととを期待した w。

\section{第 1 部ネズミコリネ菌污染}

\section{1. 病型の多様性}

二木力夫 ·高垣善男 (中外製薬)

マウスおよびラットのコリネ病は一般に，皮膚あるい は関節などの化膿を主とする病型をはじめとして, 内部 諸臟器に膿瘍形成，あるいは結腸炎など，その病型は多 岐にわたるとされている。また，たとえば cortisone 誘 発によって発症したマウスでみられるでとく，肺・腎な どの膿瘍形成と同時に盲・結腸に腫脹あるいは出血など が観察されることあある。これらの病型はかならずしあ 独立したものばかりではなく合併してみられることもあ る。

異なる病型の自然感染例病巣から分離されたコリネバ クテリウム菌については，それぞれ多少の性状の相違は 認められるが，とくにある性状の菌が，ある病型をおこ し易いということはないようである。むしろ実験感染の 成績からすれば，投与（侵入）経路あるいは動物側の条 件のいかんによって，あらわれる病型に差異が生ずると 思われる。すなわち, 皮有病型マウスからの分雑株を静 脈内接種すると, 内臟型加らの分離株と同様に, 腎 肝・肺などに膿瘍が形成されるし, 乱切した皮席への 接種では両由来株とも皮㢆の化膿を惹起する。また, 接 
種菌数を極端に多くした場合とか，あるいは接種動物に cortisone を投与した場合などでは関節炎をはじめとし て種々の病変が認められる。

一般の繁殖コロニーにおいては, 不顕性感染が多く, かなり濃厚に污染していても発症例はほとんどみられな いことがある。したがって，後述のように実験の場で発 病がみとめられる場合でも，生産コロニーの動物の剖検 によって病変を検出することとむづかしく, 検出率は数 \%あるいはそれ以下にすぎない。しかむ検出例で観察さ れる病変は大半が肺・肝などに限局された膿瘍である。

一方, 実験者が遭遇する本症の多くは, 動物の移動あ るいは動物実験における処置によって誘発・顕性化され るあのと考えられ，何らかの悪条件が重なって本症の発 生がみられるようである。比較的急性に経過するケース が多く，しかあ集団発生するととあある。その際に種々 の病型が観察され，それぞれの場合で異なる。

\section{2. 潰䕐性大腸炎}

○山田明甫 · 小河秀正 (第一製楽 · 中央研)

目的:

マウスおよびマウスにおけるネズミコリネ菌の顕性化 病像としては, 従来, 肝・腎・肺などにおける化膿性壊 死性病巣がよく知られているが，消化管特に主として盲 腸における潰瘍性病巣についての報告は少ない。

われわれは，ACTH の大量連続投与によりラットに おいて，ネズミコリネ菌による潰瘍性大腸炎の発生を経 験したので報告する。

材料と方法：

1）ラット：生後 42〜46 日龄の SD 系雄性ラットを A，B 繁殖場から購入して使用した。実験期間中，ラッ 卜は室温 $24 \pm 1^{\circ} \mathrm{C}$, 湿度 $55 \pm 5 \%$ の空調室で, 1 ケージ に 5 匹ずつ収容し，市販の固型飼料および水道水により 飼育した。2） $\mathrm{ACTH}$ 処置：日量 $2 \mathrm{mg} / \mathrm{kg}$ のC $\mathrm{TH}$ を，休日を除く毎日，背部皮下注射した。 3）病 理学的観察: 死亡例は発見後直ちに, 生存例は衰弱が著 しい例から適宜と殺して, 剖検に供した。

10\%ホルマリンで固定した臓器組織は，パラフィン切 片にし, 主として HE 染色により, 組織学的に検索し た。4）紐菌学的検索：と殺剖検例のうち, 肉眼的に 病巣が認められた一部の盲腸, 肝, 腎, 肺について, 10 \%馬血液加トリプトソン寒天培地で菌の分離を行ない, 分離菌の性状を検討した。5）感染実験：潰瘍性病巣 を有する盲腸から圧倒的多数で分離され, Corvnebacterium kutscheri と同定された菌の潰瘍惹起性を確認す る目的で， $\mathrm{A}$ 繁殖場産の $\mathrm{SD}$ 系ラット（雄，5週齢）の 静脈内および腹腔内に $10^{7} / \mathrm{ml}$ の菌を接種し, 約半数の
ラットに AC'TH およびコーチゾンを併用した。 成績:

1） $\mathrm{ACTH}$ の連続投与により誘発された潰愓性大腸 炎, 肝·腎・肺における化膿性壊死性病栄の発生頻度を Table 1 に示したが，いずれの病巣す B 繁殖場産ラッ トで高率に発生した。ACTH 無投与群では, A および B 繁殖場産ラットとも, 潰瘍性病巣, 化膿性壊死病巣は まったく検出されなかった。

2）潰瘍性病巣は, 主として盲腸に検出されたが, 一 部の例では回腸末端部および結腸起始部にもみられた。 病巣の大きさは種々で, 一般に暗赤色を呈し, 周囲組織 から明らかに区別された。組織学的には, 多数の菌塊お よび細胞核片を含む境界明瞭な壊死栄がみられ, 巣周囲 には好中球，単核球を主体とする細胞浸潤が認められ た。病巣直下の粘膜筋板は断裂または消失し, 粘膜下織 は水腫性に疎開していた。この部の血管にはしばしば血 栓の形成が認められた。

このような病巣にまじって, 粘膜固有層に, 細菌集塊 を中心とする好中球の小集蔟集がしばしば認められた。 さらに, 一部の例では, 粘膜病変の発現に先行して, 粘 膜下織の血管に, 血管壁の変性, 内皮細胞の腫大, 内膜 への好中球浸潤, 線維素血拴, 細菌栓塞, 等の変化が観 察された。

3）肝，腎，肺における化膿性壊死性病巣の発生率は 肺>肝>腎の順位を示した。肺病変が高度な例では，心 囊の白浊, 肥厚がしばしば認められた。一方, 肉眼的に は変化を見出しえなかった臟器, 例えば副腎, 脺, など にも, 組織学的に微小膿瘍が検出された。

4）潰瘍性病巣を含む盲腸および肝, 腎, 肺の化膿性 壊死性病单の細菌検索により, Corynebacterium kutssheri の性状を有する菌が王倒的多数で分離された。

5）分離菌を用いた感染実験により，ACTH あるい はコーチゾンを併用した群にのみ, 誘発病巣と同質の潰 瘍性病巣が盲腸に発現した (Table 2)。

考察:

$\mathrm{ACTH}$ を連続投与された SD 系ラットにみられた盲 腸の潰瘍性病巣ならびに肝・腎・肺の化膿性壊死性病巣 は，いずれあネズミコリネ菌によ一て惹起されることが 明らかにされた。潰煌性病巣の形成様式は，その組織 像, すなわち粘膜病変の発現に先行して, 細菌栓塞, 血 栓形成あるいは血管炎が粘膜下織の血管に認められる例 があったことから，血管変化に後続する病変のように思 われた。コリネ病の一次病巣の所在については, 従来, 種々の考え方が出されているが，今回の実験からは，肺 （気管支）にあるように思われた。しかしながら，ての 点については, 今後さらに検討を加える必要があろう。 
Table 1. Corynebacterial lesions in SD rats treated with ACTH

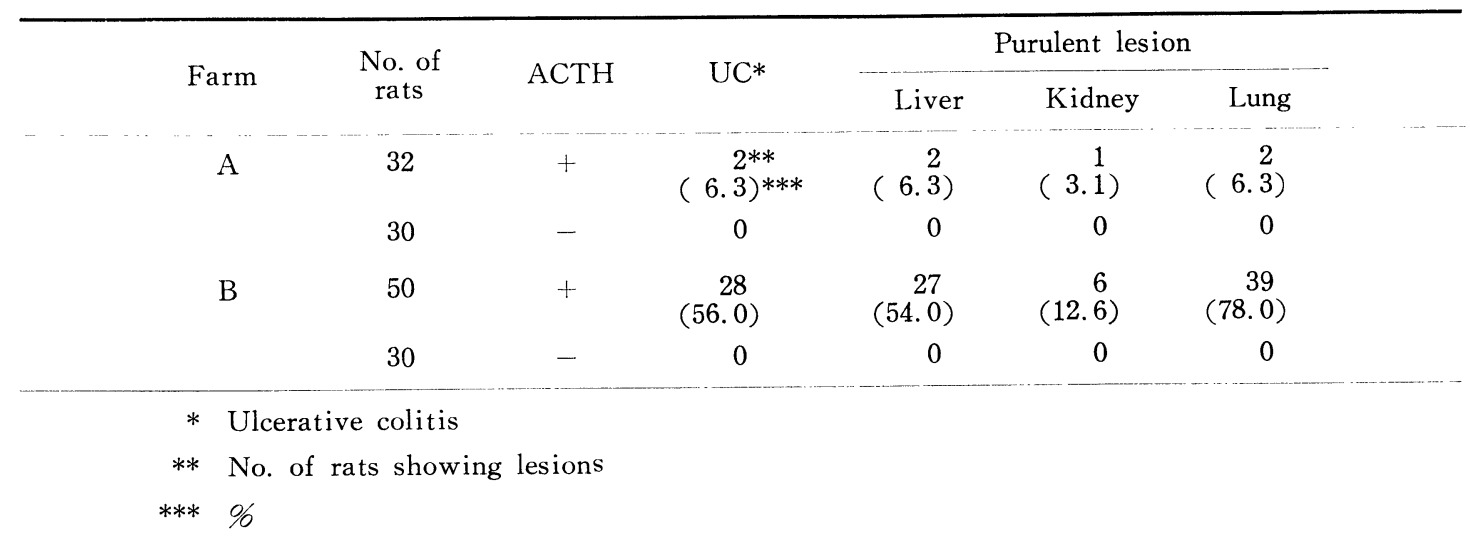

Table 2. Gross changes in SD rats (Farm-A) inoculated with C. kutscheri

\begin{tabular}{|c|c|c|c|c|c|c|}
\hline \multirow{2}{*}{ Treatment } & \multirow{2}{*}{$\begin{array}{l}\text { No. of } \\
\text { rats }\end{array}$} & \multirow{2}{*}{ UC* } & \multicolumn{3}{|c|}{ Purulent lesion } & \multirow{2}{*}{$\begin{array}{l}\text { Sweeling } \\
\text { of limbs }\end{array}$} \\
\hline & & & Liver & Kidny & Lung & \\
\hline $10^{7}$ (iv) & 4 & $0 * *$ & 1 & 0 & 3 & 4 \\
\hline $10^{7}(\mathrm{ip})$ & 4 & 0 & 0 & 0 & 0 & 0 \\
\hline $10^{7}(\mathrm{iv})+\mathrm{ACTH}$ & 4 & 4 & 2 & 4 & 4 & 0 \\
\hline $10^{7}(\mathrm{ip})+\mathrm{ACTH}$ & 7 & 5 & 6 & 7 & 7 & 0 \\
\hline $10^{7}(\mathrm{iv})+$ Cortisone & 5 & 5 & 4 & 5 & 5 & 0 \\
\hline $10^{6}$ (iv) & 4 & 0 & 0 & 0 & 1 & 0 \\
\hline $10^{6}(\mathrm{ip})$ & 4 & 0 & 0 & 0 & 0 & 0 \\
\hline $10^{6}$ (iv) $+\mathrm{ACTH}$ & 6 & 4 & 3 & 6 & 6 & 0 \\
\hline $10^{6}(\mathrm{ip})+\mathrm{ACTH}$ & 3 & 1 & 2 & 2 & 2 & 0 \\
\hline
\end{tabular}

* Ulcerative colitis

** No. of rats showing lesions

\section{3. 経口感染の成立条件}

\section{横井山 繁 行 (東洋醸造)}

はじめに

マウスのコリネバクテリウム病による污染は，わが国 のマウスコロニーで極めて普通にみられる。不顕性感染 が多く，何らかのストレスが加わった場合に発病するあ のと考えられるが, エクトロメリアウイルス・サルモネラ など，他の微生物の感染あるいは薬物投与，X 線照射な どの各種実験処置あるいは急激な環境の変化などにより 感染が顕性化されると思われる。感染経路については殆 んど不明で自然発症例に見る病変像から経口感染が推察 された。しかし，無処置マウスに毒力の高い菌を経口接 種して屯致死的感染は成立しない。そこで腸管感染の実 験ではしばしば適用される絶食処置と感染増強因子とし て知られているコーチゾン処置を組合せて, Corynebac- te rium kutscheri（以下ネズミコリネ菌）の経口感染を 試みた。

\section{経口感染実験}

Table 1 にみるように, 無処置マウス (ddY/S 系, 雄性，4 週齢，体重18-20 g）にマウスより分離したネズ ミコリネ菌 CKI 株の燐酸緩衡生理食塩液浮遊菌液をス テンレス製経ロゾンデを用いて経口接種しても発症には 致らなかった。接種直後に $5 \mathrm{mg}$ のコーチゾンを投与し たところ $35 \times 10^{8}$ 接種群は 5 匹中 2 例, $5 \times 10^{7}$ は 1 例の死亡をみた。さらに接種前 24 時間絶食させ，接種直 後 $5 \mathrm{mg}$ のコーチゾンを投与すると, $5 \times 10^{8}$ 接種群は 5 匹全例， $5 \times 10^{7}$ む 4 例が死亡した。しかしながら絶食 処置だけでは経口接種によ一て発病させることはできな かった。乾酪壊死を含む肝膿瘍の形成は，無処置および 絶食マウスには見られなかったが， $5 \times 10^{7}$ 接種直後に 
$5 \mathrm{mg}$ のコーチゾンを投与した場合には 5 匹中 1 例に見 られた。また $5 \times 10^{8}$ の菌を接種直後に $5 \mathrm{mg}$ のコーチ ゾンを投与した場合には接種前絶食の有無にかかわらず 全例に肝病変が見られた。また絶食とコーチゾン処置の 両者を加えたときは $5 \times 10^{7}$ の菌によって全例に肝病変 がみられた。肝の特異的な膿瘍のほかに, 腸管の出血, 炎症, 腹腔リンパ節の化膿, 肺 ·腎の針頭大〜帽針頭大 の化膿巣, 比較的長く生残したマウスに見られた肝の乾 酪巣など自然発症の病変と酷似した病変像が見られた。 また肝の培養結果は Table 2 にみるように，24時間絶 食後, $5 \times 10^{8}$ の菌を経口接種し, 直後に $5 \mathrm{mg}$ のコーチ ゾンを投与した場合, 接種 6 時間後では肝への菌の定 着・増殖はみられなかったのに対して，1 日後では 4 例 中 2 例, 2 日後では全例に菌が検出された。 2 日後以降 は肝の菌は急速に増殖し, 体重および肝重量の減小之之 あに肝膿瘍の形成がみられ，6日目までに使用マウスの ほとんどが死亡した。感染成立に必要なコーチゾンの投 与量については，24時間絶食させたマウスに $5 \times 10^{8}$ の 菌を経口接種し, 直後に $5 \mathrm{mg}$ のコーチゾンを投与した 場合には10匹全例が死亡したが， $2.5 \mathrm{mg}$ では 4 例， 1 $\mathrm{mg}$ では 1 例, $0.5 \mathrm{mg}$ と無投与群には死亡例はなかっ た。肝膿瘍の形成む $5 \mathrm{mg}$ 投与群では全例にみられ， $2.5 \mathrm{mg}$ では 6 例, $1 \mathrm{mg}$ では 2 例, $0.5 \mathrm{mg}$ と無投与群 にはみられなかった。またコーチゾンの投与時期につい ては，接種 3 日前投与ではまったく無効で，1 または 2 日前投与では 5 匹中 1 例のみ死亡をみたが，接種直後〜 2 日後投与では10匹全例，9１4日後投与であ10匹中 3 4 例の死亡をみた。試みたステロイドホルモン 3 種の中 で, コーチゾンのの感染増強効果があっとも強く, かつ 再現性のある成績がえられた。プレドニゾロンは約半分 の効果, デゾキシコルチコステロンはネズミコリネ病に 対してはまったく無効であった。
コリネ病の経口感染においては絶食処置とコーチゾン 投与を合わせて用いることによってははじめて強い感染 増強効果が発現すと考えられる。コーチゾンは主として 菌の組織内への侵入増殖に関して効果を発揮し, 絶食は 主として菌の消化管内における生存率と消化管上皮との 接触の可能性を高める上に効果があるものと考えられ る。 $5 \times 10^{8}$ の経口接種で全例侄死的感染を成立させ るためには，コーチゾンをマウス当り $5 \mathrm{mg}$ 投与するこ とを必要とした。このようにきわめて大量の糖質皮質小 ルモンを投与するととにより，網内系機能の抑制・抗体 産生抑制効果，あるいは局所の炎症にともなう細胞反応 阻止などにより，重い感染をおこすことになると考えら れる。コーチゾンの投与時期は菌接種直後から 1 日目ま でに投与した場合の効果があっとも強く, 菌接種後投与 までの期間が長いほど投与効果が低く，乙れは局所の炎 症反応の低下により菌の捕捉が行なわれにくくなること が感染増強効果としてあらわれることを意味すると考え られる。しかし，コーチゾンを投与しない場合であ一部 のマウスでは接種菌は宿主体内に定着するらしく，接種 後 9 日あるいは15日にコーチゾン $5 \mathrm{mg}$ を投与するとと により10例中 $3 \sim 4$ 例が発病致死する。自然にはこのよ うにして不顕性感染が成立する個体がかなりあるあのと 考えられる。

\section{おわりに}

マウスコリネバクテリウム病の経口感染は菌接種前時 24 間絶食させたマウスに $5 \times 10^{8}$ の菌を経口接種し接種 直後にマウス当り $5 \mathrm{mg}$ のコーチゾンを皮下投与するこ とにより成立し, その病変像は自然症例と酷似してい た。また，乙の実験系はコリネ病の不顕性感染をコーチ ゾン投与により発症させる反応を実験的に再現したもの であると考える。

Table 1. Effects of fasting and cortisone on peroral infection with C. kutscheri CK 1

\begin{tabular}{|c|c|c|c|c|c|c|}
\hline & \multirow{2}{*}{$\begin{array}{l}\text { No. organisms } \\
\text { inoculated }\end{array}$} & \multirow{2}{*}{ Cortisone* } & \multirow{2}{*}{ Mortality** } & \multirow{2}{*}{$\begin{array}{l}\text { Time-to-death } \\
\text { in days }\end{array}$} & \multicolumn{2}{|c|}{ Liver abscess } \\
\hline & & & & & + & - \\
\hline \multirow[t]{4}{*}{ Non-fasted } & $5 \times 10^{7}$ & - & $0 / 5$ & & & $5 * * *$ \\
\hline & $5 \times 10^{8}$ & - & $0 / 5$ & & & 5 \\
\hline & $5 \times 10^{7}$ & + & $1 / 5$ & 6 & 1 & 4 \\
\hline & $5 \times 10^{8}$ & + & $2 / 5$ & 8,8 & 5 & \\
\hline Fasted & $5 \times 10^{7}$ & - & $0 / 5$ & & & 5 \\
\hline \multirow[t]{3}{*}{ for $24 \mathrm{hrs}$} & $5 \times 10^{8}$ & - & $0 / 5$ & & & 5 \\
\hline & $5 \times 10^{7}$ & + & $4 / 5$ & $6,6,6,9$ & 5 & \\
\hline & $5 \times 10^{8}$ & + & $5 / 5$ & $6,6,6,6,6$ & 5 & \\
\hline
\end{tabular}

* $5 \mathrm{mg}$ cortisone acetate, S. C. immediately after inoculation.

** No. dead/No. tested 14 days after inoculation.

*** No. of mice having lesions. 
Table 2. Liver abscess formation and detection of organisms in fasted and cortisone-treated mice*

\begin{tabular}{cccccccccc}
\hline \multirow{2}{*}{ Day after infecion } & \multicolumn{3}{c}{ Liver abscess } & \multicolumn{3}{c}{ No. of organisms/g $(\log )$} \\
\hline $1 / 4$ & - & - & - & - & - & - & - & - \\
1 & - & - & - & - & - & - & 2 & 3.5 \\
2 & - & - & - & - & 3.2 & 3.6 & 4.2 & 4.6 \\
3 & - & - & + & - & 4.3 & 6 & 6 & 6.2 \\
4 & + & + & + & + & 7.2 & 7.2 & 7.6 & 8.2 \\
6 & + & + & + & + & 7.5 & 8 & 8.5 & 9 \\
\hline
\end{tabular}

* Fasted for $24 \mathrm{hrs}$ before and treated with $5 \mathrm{mg}$ cortisone shortly after peroral inoculation with $5 \times 10^{8}$ organisms

Teble 3. Effects of cortisone treatment made before or after peroral inoculation in fasted mice*

\begin{tabular}{|c|c|c|c|c|c|c|c|c|c|c|c|c|c|c|c|c|c|c|c|c|c|}
\hline \multirow{2}{*}{\multicolumn{3}{|c|}{$\begin{array}{l}\text { Cortisone } \\
(5 \mathrm{mg}, \mathrm{S} . \mathrm{C} .)\end{array}$}} & \multirow{2}{*}{ Mortaliry } & \multicolumn{16}{|c|}{ Time-to-death in cays } & \multicolumn{2}{|c|}{$\begin{array}{l}\text { Liver } \\
\text { absces }\end{array}$} \\
\hline & & & & 45 & 6 & 7 & 78 & 9 & 10 & 1112 & 13 & 14 & & 1617 & 181 & 192021 & 2223 & 2425 & 262 & + & - \\
\hline 3 days $\mathrm{k}$ & before & & $0 / 5 * *$ & & & & & & & & & & & & & & & & 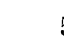 & & \\
\hline 2 days & " & & $1 / 5$ & & & & 1 & & & & & & & & & & & & 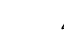 & 4 & \\
\hline 1 day & & & $1 / 5$ & & 1 & & & & & & & & & & & & & & trat & 5 & \\
\hline Immedi: & ately & afte & er $10 / 10$ & 52 & 2 & 1 & & & & & & & & & & & & & & 10 & \\
\hline 1 day & & " & $10 / 10$ & 9 & 9 & 1 & 1 & & & & & & & & & & & & & 10 & \\
\hline 2 days & & " & $10 / 10$ & & 1 & 15 & 53 & 1 & & & & & & & & & & & & 10 & \\
\hline 3 days & & " & $9 / 10$ & & & 1 & 12 & 1 & 1 & 1 & 2 & & & 1 & & & & & rata & 9 & \\
\hline 4 days & & " & $8 / 10$ & & & & 2 & 1 & 1 & 1 & 1 & 1 & & & & & 1 & & 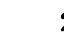 & 9 & \\
\hline 5 days & & " & $8 / 10$ & & & & & & 1 & 1 & & & ? & 3 & 1 & 1 & & & 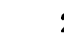 & 9 & \\
\hline 7 days & & " & $6 / 10$ & & & & & & & 2 & & 1 & 1 & & & 1 & & & 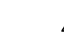 & 8 & \\
\hline 9 days & & " & $4 / 10$ & & & & & & & & & 2 & 1 & 1 & & & & & 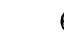 & 4 & \\
\hline 14 days & & " & $3 / 10$ & & & & & & & & & & & & & 1 & 1 & & 1 & 3 & \\
\hline- & & & $0 / 10$ & & & & & & & & & & & & & & & & 1 & 10 & \\
\hline
\end{tabular}

* Fasted for $24 \mathrm{hrs}$ befor peroral inoculation with $5 \times 10^{3}$

* See the foot-note on table 1.

\section{4. コーチゾン処置・蛍光抗体法による污染チェック}

\section{内 海 健二朗（大日本製薬）}

〔はじめに〕 マゥス・ラットにおける Conynebacterium の感染は潜在的なあのが多くストレスなどによ って顕性化することはよく知らている。それ故, 実験途 上で発症するととが多くあり, その摃失を防く意味に扔 いても Corynebacterium の感染の有無を予め調べてお く必要がある。現在, その方法として高垣 ${ }^{1)}$ らによって 行われた, マウスのコーチゾン投与による誘発試験法が 知られているが，コーチゾン投与による誘発は他の正常 動物への感染の抢それがあるため専用の感染動物室を必
要とする。また，迅速簡便な分離菌の同定法の開発も望 まれる。そてで，われわれはラットを対象として、コー チゾン誘発試験による検疫を行うと同時に，新しく蛍光 抗体法による検疫の可能性についてあ検討を加えたので それらの成績をあわせて報告する。

なお,検没の対象とした菌株は Corynebacterium kutucheri である。

[コーチゾンによる誘発試験】コーチゾン投与の条件 はラットの週龄および体重によって変わる。Selye ${ }^{2)} は$ 約 $120 \mathrm{~g}$ のラットに対して $5 \mathrm{mg} /$ body を 1 日 2 回, 12 日 間，Le Maistre ${ }^{3)}$ は 250〜350g のラットに対して同 じく $5 \mathrm{mg} /$ body を 1 日 2 回，28日間皮下へ投与してい 
表 1 ラットの週齿とコーチゾン投与量の関係

\begin{tabular}{|c|c|c|c|c|c|c|c|c|c|}
\hline \multirow{2}{*}{ 実 } & \multirow{2}{*}{ 週齢 } & \multirow{2}{*}{ 体重 } & \multirow{2}{*}{-} & 投 & 与 & 群 & 非 投 & 与 & 群 \\
\hline & & & & 検査数 & & コリーネ症 $(\%)$ & 検査数 & & 一ネ症 $(\%)$ \\
\hline \multirow[t]{4}{*}{ I } & 8 & $170 \sim 207 \mathrm{~g}$ & & 6 & & 0 & $5^{* *}$ & & 0 \\
\hline & 7 & $130 \sim 155$ & & 4 & & 0 & 3 & & 0 \\
\hline & 6 & $130 \sim 148$ & & $5^{*}$ & & 0 & 4 & & 0 \\
\hline & 5 & $72 \sim 135$ & & 9 & & $3(33.3 \%)$ & $8^{* * *}$ & & 0 \\
\hline \multirow[t]{5}{*}{ II } & 5 & $72 \sim 117$ & & 6 & & $4(66.6 \%)$ & $4 * * * *$ & & 0 \\
\hline & \multicolumn{4}{|c|}{ ＊ 他の微生物による肺炎 } & \multicolumn{2}{|c|}{1 匹 } & & & \\
\hline & & $* *$ & " & & \multicolumn{2}{|c|}{2 匹 } & & & \\
\hline & & $* * *$ & " & & \multicolumn{2}{|c|}{2 匹 } & & & \\
\hline & & $* * * *$ & " & & \multicolumn{2}{|c|}{1 匹 } & & & \\
\hline
\end{tabular}

表 2 Breeder A より購入ラットひ発育不良ラットの発生率

$$
\text { -1968 1973- }
$$

$\mathrm{n}>400$

\begin{tabular}{cccccrrr}
\hline & 68 & 69 & 70 & 71 & 72 & 73 年 & 平均(\%) \\
1 月 & $19.2^{*}$ & 4.2 & 1.7 & 26.1 & 6.3 & 3.4 & 10.2 \\
2 & $35.0^{*}$ & 5.4 & 9.7 & 17.2 & 11.4 & 5.9 & 14.1 \\
3 & $15.0^{*}$ & 6.3 & 2.7 & 24.7 & 8.6 & 5.9 & 10.5 \\
4 & $16.0^{*}$ & $9.5^{* *}$ & 22.4 & 11.2 & 8.0 & 6.5 & 12.3 \\
5 & 16.4 & {$\left[1.2^{* *}\right.$} & 14.0 & 7.7 & 7.4 & 7.1 & 10.6 \\
6 & 22.6 & $9.6^{* * *}$ & 12.8 & 4.7 & 8.9 & 9.6 & 11.4 \\
7 & 24.8 & $18.6^{* * *}$ & 8.1 & 9.0 & 11.2 & 7.3 & 13.2 \\
8 & 4.7 & 19.4 & 3.0 & 5.2 & 10.7 & 12.2 & 9.2 \\
9 & $11.6^{* *}$ & 8.5 & 3.1 & 9.0 & 12.7 & 9.6 & 9.1 \\
10 & $6.3^{* *}$ & 16.1 & 12.5 & 5.5 & 9.4 & 6.4 & 9.4 \\
11 & 10.0 & 6.8 & 6.5 & 3.3 & 3.8 & 8.7 & 6.5 \\
12 & 3.0 & 4.4 & 5.3 & 2.4 & 4.4 & $7.0^{* 3}$ & 4.4 \\
\hline 平均 & 15.4 & 12.0 & 8.5 & 10.5 & 8.6 & 7.5 & -
\end{tabular}

* 1968年第 3 回研究発表会で報告（コーチゾン処置によるラット潜在感染誘発例について）

** 末発表（コーチゾン非投与発育不良ラット中の自然感染による肺病変よりC.kutscheriの分離）

****末発表（コーチゾン処置）

る。われわれは $70 \mathrm{~g} \sim 200 \mathrm{~g}$ のラット（週歯 5 〜 週） に対して，両者と同じ $5 \mathrm{mg} /$ body を 1 日 1 回，10日間 筋肉内へ投与した。ての投与条件では表 1 に示すごと く，2 回の実験をあわせると 5 週齢，体重 $100 \mathrm{~g}$ 前後のラ ットにおいて15匹中 7 匹約 $47 \%$ の誘発率を示した。

この実験では $5 \sim 8$ 週粭の発育不良ラットを主に選ん で行った。Corynebacterium 病の部断はコーチゾン投 与後11日目に剖検し, 病変臟器中の膿瘍形成の有無の観 察および病変臟器の培養による確認により行った。

実験 I では 6 ～週㱓において 1 例も誘発されなかっ たのに反し， 5 週齿では 9 匹中 3 匹 (33.3\%) が誘発さ れた。これを確認するために 5 週秢のラットのみで行っ
た実験 II では 6 匹中 4 匹（66.6\%）の高い誘発率を示し た。

そこで, 先の投与条件でコーチゾン投与し, 污染の検 出を行った。

発研究所で1968〜 1973年の 6 年間にA業者より購入し たラットのうち発育不良ラットの発生率を表 2 に示し た。

1967年 1〜4月までの発䏍不良ラットの中に多くの Corynebacterium病が潜在として含まれていたてとは既

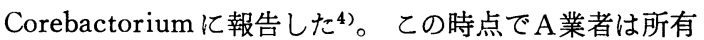
の繁殖集団を全て淘汰し Corynebacterium 病の駆除に つとめたという。しかし，その年の 9 -10月に購入した 
3 表 Corynebactrium kutscheri 検出の蛍光抗体法の基礎的検討

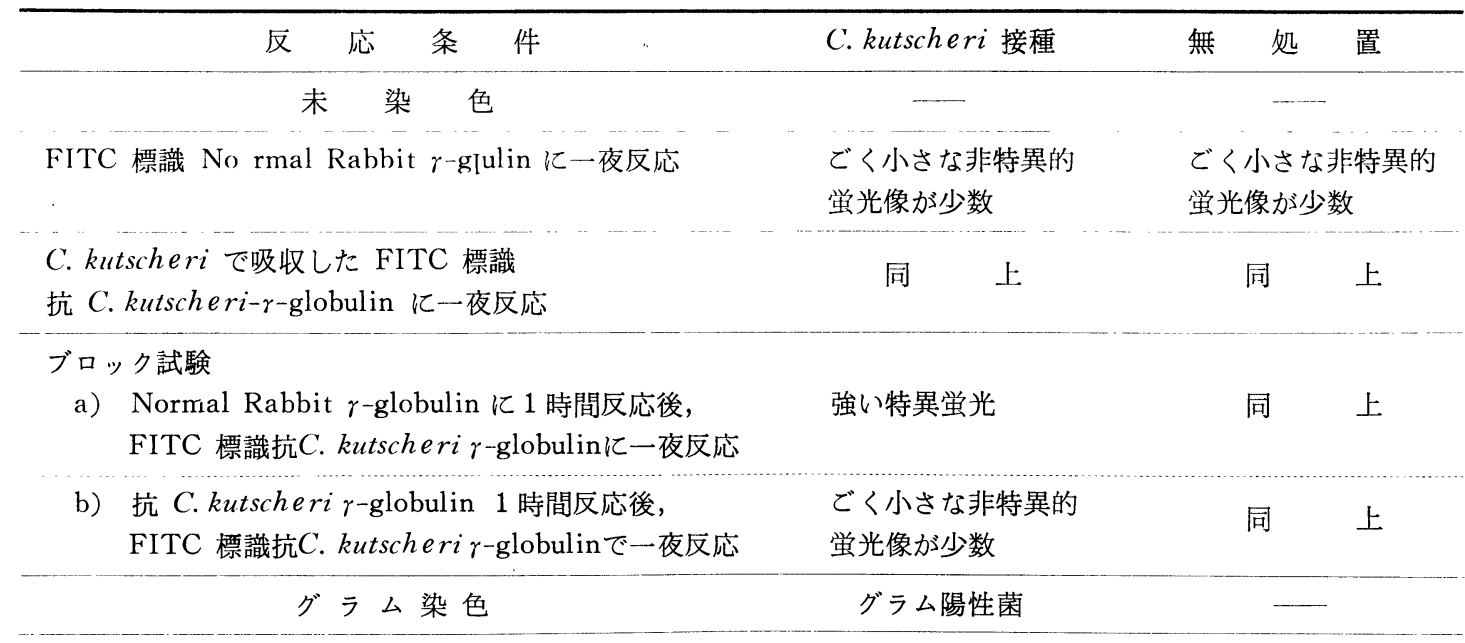

1,150匹より発育ラット105匹を選び無処置のまま解剖し たところ，70匹に肺炎を認めたので，その肺病巣を培養 したところ 7 匹に Corynbacterium kutschari を検出し た。そして，1969年 $4 \sim 7$ 月に購入した 2,285 匹中，発 育不良ラット 237 匹についてコーチゾン処置を行ったと 乙 121 匹に肺炎を認め, 内69匹 (55.3\%) が Corynebucterium 病であることが判明した。更に，5年後の 1973年12月に購入した130匹より 13 匹を無作為に選び誘 発実験を行った結果でも，8匹よりC. kutscheri を検 出した。以上の成績より 1968年 8 月〜 1973年11月までの 間にもかなり污染があったととが推測出来る。

[蛍光抗体法による検疫の検討] Brain heart infusion 寒天培地で 48 時間培養した C.kutscheriを $1 \%$ ホル マリンで24時間処理して殺し, 生理食塩水に懸濁化した あのを抗原として用いた。ての抗原液を等量のフロイン ド不完全アジバントと混ぜウサギに免疫して抗血清を作 製した。免疫は次のようなスケジュールで四肢の踓およ び背皮下の数個所に分けて注射して行った。先ず， 6.0 $\times 10^{8}$ 個の菌で初回免度し，10日後に $2.6 \times 10^{9}, 44$ 日後 亿 $4.5 \times 10^{8}$ 個の菌で惹起注射を行い, 3 回目の注射後 6 日目に全採血を行った。血清を分離した後, 常法通り ${ }^{5)}$ に硫安法书よび DEAEセルローズカラムで $\gamma$-グロブリ ン分画を精製し, Fluorescein iso-thiocyanate (FITC) で標識して用いた。調整した FITC 結合抗 C. kutscheri ウサギrーグロブリンで組織中の C.kutscheri が染まるこ とを確めるために，4〜5週齢のラットに $3.6 \times 10^{7}$ 個 の死菌を静注し, 2 時間後に肺, 肝, 脾を摘出してクリ

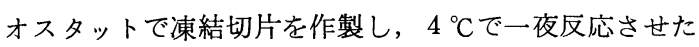
後, 蛍光顕微鏡で観察した。さらに表 3 亿示したよう な種々の対照実験を行い C. kutscheri だけが特異的に 染色されているととを確認した。この結果はグラム染色
による方法とも一応一致した。以上より，解決しなけれ ばならない技術上の種々の問題がまで若干残ってはいる あのの, C. kutscheri 感染の検疫方法として蛍光抗体法 が応用出来る可能性が判明した。

[おわりに]C.kutscheri の感染検出法として, コー チゾン誘発試験法と蛍光抗体法を述べた。前者は検疫方 法として実用は出来るが，さらに期間短縮をすれば一層 の有効手段となると考える。後者は未だ手につけたとて ろで，まだまだ難問題が山積している。技術的なととが 解決しても, 他の微生物に上る感染症との cross 反応 など，実用までにはこれから数段階を通過せねばならな い。

\section{[文献]}

（1）高垣善男 - 内貴正治 - 伊藤昌子 - 野口午郎 - 藤原公 策; マウスの Corynebacterivm 病および Tyzzer 病污 染のコーチゾン投与による検出。実験動物 $\mathbf{1 6}, 12 \sim 19$ (1967)。

(2) Selye, H. ; The influence of STH, ACTH and cortisone upon resistance to infection. Cand M. A. J. $74 \quad 489 \sim 494$ (1951)

(3) Le Maistre, C. and Tompsett, R. ; The emergence of pseudotuberculosis in rats given cortisone. J. Exp Med., 95 393-407 (1952)。

(4) 内海健二朗 - 松井幸春 - 石川隆司 - 深川清二 - 辰已 熙・藤本克郎・藤原公策; ラットの Corynebacterium 潜在感染の cortisone 処置による摘発について。実験動 物 18 59 67, (1969)。

(5) 川村明義; 蛍光抗体法·蛋白質 - 核酸 - 醉素編集部 ·免疫の生化学, 214 228 共立出版 (1972)。 


\section{5. 血清抗体による污染チェック}

松 沼 尚 史（三共·中央研）

マウス・ラット繁殖集団におけるネズミコリネ菌污染 を検出する方法としては, cortisone 誘発試験や血清抗 体を検索する方法などがある。しかし，誘発試験り場合 には, 発症した動物から病原体を正確に分離固定するこ とが必要であったり，余程注意しないと試験そのあのが
再び污染源となりかねない危険を伴っているという問題 がある。したがって, 退役種親の血清を用いた抗体検索 （藤原，1967）が現在もっとも簡便で有効な方法とされ ており，マイクロタイタートレイを利用すれば，多数の 検体を比較的短時間で効率よく処理することができる。 この方法を用いて, いわゆるbarrier system (BS) で維 持されている帝王切開由来の繁殖集団と, いわゆるconventional $(\mathrm{CV})$ 環境で維持されている繁殖集団につい

Table 1. Checking of antibodies against five infective agents in retired breeder mouse sera

\begin{tabular}{|c|c|c|c|c|c|c|c|}
\hline \multirow{3}{*}{ 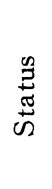 } & \multirow{3}{*}{$\begin{array}{c}\text { Year } \\
\text { collected }\end{array}$} & \multirow{3}{*}{$\begin{array}{c}\text { No. } \\
\text { tested }\end{array}$} & \multicolumn{5}{|c|}{ Antibody detection (\%) } \\
\hline & & & \multicolumn{2}{|r|}{$\mathrm{CF}$} & \multicolumn{3}{|c|}{ Agglutination } \\
\hline & & & $\begin{array}{l}\text { Tyzzer's } \\
\text { agent }\end{array}$ & $\begin{array}{c}\text { Hepatitis } \\
\text { virus }\end{array}$ & $\begin{array}{l}\text { Sendai } \\
\text { virus }\end{array}$ & $\begin{array}{c}\text { Corvnebact. } \\
\text { kutscheri }\end{array}$ & $\begin{array}{l}\text { Sal. } \\
\text { enteritidis }\end{array}$ \\
\hline \multirow{5}{*}{ D. } & 1969 & 1770 & $1(0.05)$ & 0 & $7(0.4)$ & $5(0.3)$ & 0 \\
\hline & 1970 & 2147 & 0 & 0 & 0 & $1(0.04)$ & 0 \\
\hline & 1971 & 2278 & 0 & 0 & 0 & 0 & 0 \\
\hline & 1972 & 2666 & 0 & $2(0.07)$ & 0 & $8(0.3)$ & 0 \\
\hline & Total & 8861 & $1(0.01)$ & $2(0.02)$ & $7(0.07)$ & $14(0.2)$ & 0 \\
\hline \multirow{3}{*}{ 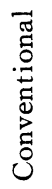 } & 1969 & 903 & 0 & 0 & $147(16.3)$ & $10(1.1)$ & 0 \\
\hline & 1970 & 534 & 0 & 0 & 0 & 0 & 0 \\
\hline & Total & 1437 & 0 & 0 & $147(10.2)$ & $10(0.7)$ & 0 \\
\hline
\end{tabular}

Table 2. Checking of antibodies against four infective agents in retired breeder rat sera

\begin{tabular}{|c|c|c|c|c|c|c|}
\hline \multirow{3}{*}{ 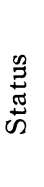 } & \multirow{3}{*}{$\begin{array}{c}\text { Year } \\
\text { collected }\end{array}$} & \multirow{3}{*}{$\begin{array}{c}\text { No. } \\
\text { tested }\end{array}$} & \multicolumn{4}{|c|}{ Antibody detection $(\%)$} \\
\hline & & & \multicolumn{2}{|c|}{$\mathrm{CF}$} & \multicolumn{2}{|c|}{ Agglutination } \\
\hline & & & $\begin{array}{l}\text { Tyzzer's } \\
\text { agent }\end{array}$ & $\begin{array}{c}\text { Sendai } \\
\text { virus }\end{array}$ & $\begin{array}{c}\text { Corynebact. } \\
\text { kutscheri }\end{array}$ & $\begin{array}{l}\text { Sal. } \\
\text { entertidis }\end{array}$ \\
\hline \multirow{5}{*}{ 䓫 } & 1969 & 1560 & 0 & $4(0.3)$ & $3(0.2)$ & 0 \\
\hline & 1970 & 2822 & 0 & 0 & $6(0.2)$ & 0 \\
\hline & 1971 & 2053 & 0 & 0 & $5(0.2)$ & 0 \\
\hline & 1972 & 2622 & 0 & 0 & $4(0.2)$ & 0 \\
\hline & Total & 9057 & 0 & $4(0.04)$ & $18(0.2)$ & 0 \\
\hline \multirow{4}{*}{ 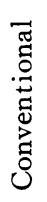 } & 1969 & 720 & 0 & $81(11.3)$ & $7(1.0)$ & 0 \\
\hline & 1970 & 320 & 0 & 0 & $6(1.9)$ & 0 \\
\hline & 1972 & 500 & 0 & 0 & $3(0.6)$ & 0 \\
\hline & Total & 1540 & 0 & $81(5.3)$ & $16(1.0)$ & 0 \\
\hline
\end{tabular}


て検査を行った。

1969 1972年の 4 年間に BS のラット9057例，マウス 8861 例を検査し，いずれあ抗体陽性率 $0.2 \%$ であった (Table 1., Teble 2)。ところで, 繁殖集団の污染于エ ックを行う場合，その結果に一例で屯陽性例があれば, 検査した動物群が污染していると判定するのが原則的な 考え方である。そとで，乙の陽性例がネズミコリネ菌の 污染を正しく摘発しているか否かを明らかにする為に検 討を加えた。まず，検査した全個体の解剖検査では一例 あ病変が検出されていないとと, 更に, 同じ時期に行っ ていた定期的な cortisone 誘発試験では, 計1500匹のマ ウスで観察期間中死亡例はなく, 病変, 菌分離いずれも 陰性であった。また，乙れらの陽性血清は，再試験をか ねて抗体力価を測定したところ，32倍の血清稀釈で陰性 を示すあのがあり，最終的に約 $0.03 \%$ の陽性率となっ た。したがって，乙の $0.2 \%$ 陽性例は，非特異的な疑 集反応を示すあのであろうと考えた。一方, 同じ時期 に，飼育管理者，施設の異なる CV のラット 1540 例，マ ウス 1437 例を検査し抗体陽性率は各々 $1.0 \%, 0.7 \%$ であ り, 再試験をかねた抗体力価測定試験によっても同じ成 績が得られた。しかあ, 剖検時ラットにおいて約 $7.5 \%$ の動物の肺に膿瘍が検出された。

以上, マウス・ラット繁殖集団ひネズミコリネ菌污染 を検出する方法として, 退役種親の血清を用いてその抗 体を検索する方法は有効である。しかし，少くとも 0.2 \%程度の非特異反応が表れるので, 解剖検査, cortisone 誘発試験，抗体力価の測定などを行ってそれを確認する 必要がある。尚, この方法の問題点として他に 2 つ程指 摘することができる。その 1 つは，退役種親を用いるた め検査する繁殖集団によっては, 半年に 1 度位の検査と なってしまい，その間に起った励染は取り返しのつかな い程拡大してしまう可能性があるというととである。 その対策として, 出来れば検査する集団の中に定期的に 検査する為のモニターを飼育すれば良いであろう。他の ひとつは, 試験用抗原としてのネズミコリネ菌の保存, 抗原の作成, 抗原性の確認などの手数がかかるというこ とである。

\section{第 2 部 センダイウイルス}

\section{1. 病変亡病型}

\section{武藤健（国立予研）}

マウスコロニーにおけるセンダィウイルスの流行に関 連して, ウイルスの性状, ウイルスの分離状況, 血清学 的扰よび疫学的の検討はかなり進展している。しかし宿 主であるマウスの病変については今まで系統的な検査報
告はみられなかった。最近, Robinson (1968), Appell ら（1971）らの報告で, センダイウイルスの発病病理が 明らかにされ, 発病過程については比較的明確になって きた。センダイウイルスの持続感染の存在については否 定的であり, 治癒過程についても検討が行なわれていな い。今回，センダイウイルスを感染させたマウスについ て280日の長期にわたって病理学的および血清学的に検 索した。センダイウイルスの病変と病型について述べ る。

実験材料扎よび方法：マウスは SPF の $\mathrm{dd} / \mathrm{Y}$, 一部 ICR, CF\#1, gpc 系む使用した。ウイルスは自然発生例 のマウス気管由来株を梛化鶏卵にて 2 回継代した。感染 方法は $10^{8.2} \mathrm{EID} 50 / \mathrm{m} \ell, \mathrm{HA}$ 価 1:256のウイルス乳剂を経 鼻感染させ, 次いで感染マウスを飼育ケージに同居させ て感染させる接触感染方法を用いた。検査は遂日あるい は遂週的にマウス殺処分し，剖検を行ない，細菌学的検 查および血清中の $\mathrm{HI}$ 抗体の測定を行なった。組織はホ ルマリンおよびカルノア固定, パラフィン切片を作成 し, H-E, Mallory-Azan, PAS 染色を施して鏡検し た。

\section{1. 肺病変の発現日および発生率}

肺病変が肉眼的にみとめられるのは早いもので感染後 $3 \sim 4$ 日， 6 日以後には肺に明らかな病変形成がみとめ られた。肺病変の発生率は検査総頭数 192 頭のマウス中 119頭汇病変がみられ，62.0\%の発生率であった。検査し た 40 週までの肺病変の発生率の 推移は次のようであっ た。 1 週では $55 \%$, 次第に発生率が増加し， 3 週では91 \%に達した。4 週では減少がみられ60\%になった。その 後は著るしい増減がなく50 60\%の発生率が40週まで持 続してみられた。外国の報告では肉眼的の肺病変の記載 も殆んどなく, 肺病変が高率にみとめられた今回の成績 とは著るしく異なっていた。乙れは使用したウィルスの 毒力, マウスの系統および飼育環境の差異等が考えられ るが，今後検討を加えることが必要である。

2. 肺病変の病理

(1) 肉眼的所見; センダイウイルス感染の肺病変につ いては感染の病期によって所見が異なっていた。したが ってその所見により, 初期 $(1 \sim 7$ 週 $)$ 病変と後期 ( 8 ～40週）病変に大別し得た。初期病変をさらに单状性病 変と赤色充実性病変に分け, また後期病変も線状性病変 と無気肺性病変の 2 つに分け得た。初期の巣状性病変は 肺の各分葉に $1 \sim 3$ 力所, 円形の赤褐色の小病巣がみら れた。病変は感染経過ととあに拡大し， $3 \sim 4$ 週では大 きな病巣がみとめられた。赤色充実性病変は通常 1 分葉 に限局し, 赤色で充実した病変が分葉全体にみられた。 この病変の発生頻度は巣状病変に比べて少なかった。後 期病変は初期病変が病期の進展によって移行したものと 
思われた。すなわち，線状性病変は初期の巣状性病変か らの移行像であり, 無気肺性病変は赤色充実性病変から 移行した。線状性病変は気管支走行汇沿って, 周囲肺実 質から陥凹した細い線状の病変がみられ，無気肺性病変 は分葉が完全に無気状となり容積の縮少した黄褐色の病 変がみとめられた。

(2) 組織学的所見; 組織学的所見は概括すると，感染 初期には壊死性炎がみられ, 次いで繁殖性炎に移行し た。乙の繁殖性炎像は感染の後期にも引続き持続してみ られた。2 4 日では大気管支に限局した上皮の変性, 好中球の浸潤がみられ，気管支の未梢および肺胞に病変 が波及した像もみられた。 4 〜 6 日では細気管支上皮の 空胞化, 核の崩壊, 好中球の渗出がみられ, 変性上皮細 胞の細胞質内に $1 \sim 3 \mu \mathrm{m}$ 位の明彙形成の好酸性封入体が

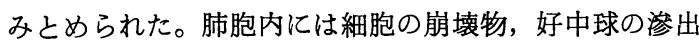
がみられた。また限局性の気管支上皮の壊死・脱落によ って粘膜の糜爛がみられ, 気管支腔内に多量の崩壊物, 好中球の滲出がみとめられた。血管および気管支周囲に はリンパ球の浸潤がみられた。との病期の所見は巣状性 肺炎あるいは気管支肺炎像であった。10日頃から気管支 上皮の肥大および増生が著明になり，乙の上皮細胞には 線毛が欠如していた。周辺肺胞内には細胞の崩壊物，好 中球および大食細胞がみられた。21日では大気管支部の 上皮の肥大·増生に軽度であるが，終末気管支上皮の増 生は著明で，巨細胞様の細胞も散見された。肺胞内には 好中球がへり，大食細胞が多くみとめられた。気管支お よび血管周囲のリンパ球の増生は著明であった。56日で は終末気管支上皮の肥大・増生, 気管支および血管周囲 のリンパ球増生は著明であり, 周辺肺胞は無気性で胞内 に泡沫細胞を入れていた。しかし, 無気肺性病変ではや や異なっており,肺門部の気管支腔は細胞崩壊物, 炎性㳒 出物によって閉塞されていた。分葉全体は無気性で, 肺 胞上皮の軽度の増生と胞内に泡沫細胞が散見された。す なわち退縮性肺炎像であった。その後も同様の所見が持 続してみられた。初期の組織学的所見は今までの報告と ほぼ同様であった。繁殖性炎の像が長期にわたって持続 していた所見は今まで報告されていない。ての所見から センダイウイルスの持続感染が強く示唆される。

3. HI 抗体価の推移

感染後 2 週から 40 週まで血中 $\mathrm{HI}$ 抗体価を測定した。 その推移については有肺病変マウスでは $\mathrm{HI}$ 価が 2 週で で $\geqq 1 ： 1024$ あり，その後40週までその抗体価が持続し てみられた。無病変マウスでは HI価が 2 週で $\geqq 1: 1024$ であったが， 6 週から下降し始め，20週で<1:16の抗体 価に低下した。肺病変の発生率の推移と HI 抗体価の推 移とはよく一致していた。

5. 病型
センダイウイルス感染の病型については, 肺病変の発 生率扰よび持続期間, 病理学的所見および HI 抗体価つ 推移の成績から，マウスのセンダイウイルス感染相を次 の 2 型に分けるのが適切と考えた。1つは急性感染型で, これは感染が急性の経過をとり, 早期に治療する病型で ある。あう1つは慢性持続感染型で，乙れは感染が慢性 の経達をとり, 長期にわたって持続する病型である。急 性感染型は従来の報告にみられるものとよく一致してい た。慢性持続感染型の報告はみられていない。今後, 七 ンダイウイルスの疫学および血清学的猃断の面からも慢 性持続感染型の病因学的の検索が重要であると思われ た。

\section{2. 重複感染}

\section{中川雅 郎 (予研)}

細菌やウイルスの病原性は, 通常各病原体の単独感染 を基にして論じられており，2種以上の異なる病原体が 同時に重複感染した際に，それぞれの病原性がどのよう に修飾されるかについてはてれまであまり検討されてい なかった。しかし最近では, 主としてヒトや動物の呼吸器 疾患で細菌とウイルスの synergistic な感染が注目され るようになり, 重複感染の重要性が認識されてきた。た とえば, ライノウイルスと Mycoplasma hyorhinis, セ ンダイウイルスと Hemophilus influenzae や Pasteurella pneumotropica などの組合せによる重複感染や, インフルエンザウイルスと Staphylococcus aureus, Hemophilus influenzae あるいは Mycoplasma hyorhinis が同時に感染すると, それらの細菌は, 単独感染 時にくらべて，はるかに強い病原性を発揮するととが知 られている。その原因については, ウイルスの感染によ って, 宿主の抵抗性が低下するとと, 細菌の増殖が促進 されること，あるいは菌の virulenceが 増強するとと， などが示唆されている。

われわれはてれまでに，マウスにみられる呼吸器疾患 の原因ならびにその発病機転を知る目的で，種々の病原 体についてマウスに対する感染性あるいは起病性を検討 してきたが，その過程で, Mycoplasma pulmonis の起 病性がセンダイウイルスの感染によって増強されること を知った。乙の現象は, 以下に述べる通り, 自然感染例 によって示唆され，感染実験によって確認された。

\section{自然感染例}

野外における26のマウス繁殖コロニーについて，マウ スに対する肺炎起炎性が問題視されている Pasteurella pneumotrop?ca $(\mathrm{Pp})$, Corynebacterium kutscheri $(\mathrm{Ck})$, Mycoplasma pulmonis (Mp) およびセンダイウイルス (HVJ) の 4 種病原体を対象に, それらの污染状態とマ ウスの肺病変発現の関係を調べたところ, 次の諸点が明 
らかになった。すなわち，1)いずれの病原体にあ污染し ていないコロニー，Pp にのみ污染した 6 コロニーおよ び Pp と Mpの 2 種病原体に污染した 4 コロニーでは肺 病変陽性マウスは検出されなかった。2) HVJ のみかあ るいは Pp と HVJ の 2 種病原体に污染した 6 コロニー では, 肺病変腸性マウスが高率に検出されるコロニーと ほとんど検出されないコロニーが相半ばした。3） Pp， $\mathrm{Mp}, \mathrm{HVJ}$ の 3 種病原体に污染した 3 コロニーおよび $\mathrm{Pp}, \mathrm{Mp}, \mathrm{Ck}, \mathrm{HVJ}$ の全種病原体に污染した 4 コロニ 一では被検マウスの10〜35\%に病変を認め, 病変部から は高率に，しかも多数の Mp が分離された。とれらの 成績から, マウスの肺病変の大部分は $\mathrm{Mp}$ と $\mathrm{HVJ}$ の感 染によって形成されるものと考えられる。しかし, Pp と $\mathrm{Mp}$ の混合污染コロニーで肺病変陽性例がなく，とれ に HVJ が更に污染すると Mp 性の肺炎例が多数検出さ れたととは，Mp の肺炎形成に HVJ の重複感染が必要 であるととを示唆している。

\section{感染実験}

マウスの肺病変形成における $\mathrm{Mp}$ と $\mathrm{HVJ}$ 感染の関 係を更に詳細に検討するために， semi-conventional な 環境のアイソレータ（飼料と飲水だけを未滅菌で与え， 他はすべて滅菌）内に SPF マウスを収容し, contact infection によって Mp 単独, HVJ 単独执よび $\mathrm{Mp}+$ HVJ の重複感染マウスを作って肺病変の発現を調べた。 その成績を要約すると以下の通りである。

$\mathrm{Mp}$ 単独感染例 - $\mathrm{ddY}, \mathrm{DDY}, \mathrm{ICR}, \mathrm{NIH}, \mathrm{C} 3 \mathrm{H} /$ $\mathrm{He}$ の 5 系統のマウスに Mp を感染させたところ，いず れの系統マウスあ鼻や気管からはほぼ $100 \% \mathrm{Mp}$ が分離 されたが, 肺病変の形成は系統によって大差がみられ た。すなわち，ICR マウスでは $57 \%$ に肺病変が形成され たのに対して, ddY, DDY 系マウスでの病変検出率は $3 \%$ 前後にとどまり, $\mathrm{NIH} \cdot \mathrm{C} 4 \mathrm{H} / \mathrm{He}$ 系マウスでは $1_{0}$ 〜20\%の陽性率を示した。いずれの系統マウスにおいて 屯形成された肺病変部からは常に Mp が多数分離された のに反して，正常肺からの Mp 分離率は ICR で $19 \%$, ddY, DDY ではいずれあ $6 \%$ であって，菌数あ少なか った。

HVJ 単独感染例—ddY系マウスにHVJを contact infection させると, contact 後 2 週以内に全例が本ウ イルスに感染して抗体が陽転した。これと同時に, 肺病 変もほぼ全例のマウスにおいて形成された。その後, 約 半数のマウスでは, 軽度ながらも, 長期にわたって病変が 持続したが，残りの半数は $7 \sim 10$ 週で治瘾して肺病変は 陰性となり，一部に抗体価の低下するあのあみられた。

$\mathrm{Mp}$ と HVJ の重複感染例—-Mp 単独感染ではほと んど肺病変を形成しない $\mathrm{ddY}$ 系マウスに $\mathrm{Mp}$ と $\mathrm{HVJ}$ を同時に重複感染させると，例外なく重度の肺病変を形
成し，しかも，一度形成された病変はほとんど治瘾する ことなく，少なくとあ 20 週以上にわたって持続した。そ して，乙れらの病変部からほぼ100\%の頻度で Mp が多 数分離された。一方, $\mathrm{Mp}$ 単独感染マウスと $\mathrm{Mp}+\mathrm{HVJ}$ の重複感染マウスについて気管ならびに肺における $\mathrm{Mp}$ の増殖状態を経日的に測定した。その結果，Mp の増殖 は, 気管，肺ともに，HVJ の重複感染によって著しく 促進されることが証明された。

以上の成績から, Mp の肺病変起病性は $\mathrm{HVJ}$ の重複 感染によって増強されることが明らかになった。その機 序については今後の研究で解析されなければならない が，HVJ の感染には, 他種病原体の起病性を増強する 一側面のあることをとこに紹介した。

\section{3. ウイルスの伝播}

$$
\text { 飯 田毅（三共中央研究所） }
$$

目的:

HVJ はマウス呼吸器系自然感染病原ウイルスの一つ で，国内マウスコロニーのほとんどがこれによって污染 されている。しか屯，不顕性感染型として持続的に存在 していることの多いのが特徵である。したがって, 人イ ンフルエンザのモデルとして, 感染, 免疫に関する研究 に，乙の組合せを用いるととは不適当であった。その 後, 当研究所で SPF マウスの生産が開始されるに至 ったので，乙のマウスを用いて HVJ の伝播，また母仔 間抗体移行に関する問題について検討を行った。既発表 (1972，1973)のあのであるが，その結果についてのべる と共にコロニー内での感染の持続性に関する考察を試み る。

方法：

ウイルス 予研武内安恵博士より分与をうけた $\mathrm{MN}$ 株。感染漿尿膜腔液 (6.2log EID $50 \mathrm{~m} \ell$ ) を- $80^{\circ}$ に凍 結保存, 用時融解使用した。

マウス 当研究所袋井飼育場生産 SPF-RFVL 系 4 週, 雌。当時, 過去 4 年以上, 補体結合反応 (CF) での 抗体チェックで感染無しとされていたコロニ一由来であ る。

接触感染方法 軽度エーテル麻酔下, ウイルス液小滴 を両鼻孔内に滴下 (3.5 log EID50) 感染させ，その 1 匹 (Infector) を 1 群10匹の正常マウス群 (Contact) に 入れ, 一定時間同居接触感染させ, 以後個別飼育とし, 21 日後に検した CF 抗体陽性率からウイルスの伝播性を 検討した。

飼育法 木屑を床敷とし, 高圧滅菌されたステーンレ ス金網蓋つきアルミケージ $(32 \times 22 \times 12 \mathrm{~cm})$ に群別, conventional な条件下で, マウス実験室より離れた実 験室一隅で飼育観察した。 
乳飲マウス経鼻感染法 Wagner(195̄5) の方法で, 10 倍稀鄱ウイルス液約 $0.01 \mathrm{~m} \ell$ を鼻孔に滴下，4 週間生死 を観察 LD50/0.1m $\ell$ を算出すると共に，生残マウスで の $\mathrm{CF}$ 抗体上昇の有無を検討した。

補体結合反応 HVJ 抗体フリーのモル血清プールを 補体とし, その 2 充単位, 抗原 4 単位（ $8 \sim 16$ 倍稀釈ウ イルス液）を用い，Sever（1962）の microtiter 法で実 施した。

中和試験 (NT) 100EID50 のウイルスに対し，常法 に従い捊化鶏卵内接種法で，50\%血球凝集素産生抑制血 清稀釈倍数を算出した。

\section{成績：}

正常マウスで $100 \%$ の伝播をみるためには，感染 0 日 からの Infector と少くとも 3 日間同居させ， $3 \sim 4$ 週 間後に採血された血清について CF テストをする必要が あり，ての条件での Infector に対する最少ウイルス量 は 1〜2 Log EID 50であった。一方, Infector に100\% 抗体陽転化を惹起させる最少量は略 $0.1 \log$ EID 50で, 不顕性感染に対し極めて高い感受性を有するマウス系で あった。

接触時間を 24 時間宛とし, Infector鼻腔組織内 $\mathrm{HVJ}$ 量 の推移と伝播率との関係をみると, $10 \%$ 組織乳剂 $0.2 \mathrm{~m} \ell$ 当り $6 \sim 7 \log$ EID50 值をしめす感染 $2 \sim 6$ 日目の Infector で，夫々 100\%の伝播があたらされた。4.5 log EID50 をしめす感染 7 日目の Infector からの伝播は44 \%であった。その後の実験結果から, 感染 3 日目の Infector の の24時間接触で100\%に伝播が成立することが 確認され，以後ての条件で実験を行っている。

3 日間接触感染実験の場合, 逐日的に Contact の鼻 㤏組織, 気管および肺内ウイルス量を餒化鶏卵接種法で 定量すると, $3 \sim 5$ 日後にウイルス検出陽性となり, 7

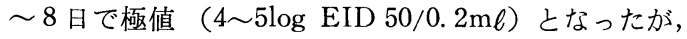
10 日後には最早検出出来なかった。

これらの実験を通じ, 非接触対照群での陽性例は皆祝 であった。

他方，1967年 8 月から翌年11月まで，1 クローズドマ ウスコロニーより 4 週マウス10匹宛について, 毎週継続 的に CF 抗体価を測定したところ，1968 年 4〜 7 月を 除き, 毎時 4 〜 倍の $\mathrm{CF}$ 抗体価を示めす頻度はほとん ど $100 \%$ に近くあった。別にそれらマウスを飼育室内で 飼育すると 4 ～週後著明な抗体上昇がみられたので, 4 週秢で検出された抗体は, 親マウスよりの移行残存抗 体と考えられ, 免疫 SPF マウスでの母仔間抗体移行に 関する検討を行い以下の知見を得た。

1 日噛で CF 抗体の検出され例ああったが, 授乳日 数と共に抗体価が上昇, $1 \sim 2$ 週齢で最高に達し， 3 週 以後漸次下降した。NT 抗体価の推移む略同様であっ
た。移行抗体は IgGで, $\operatorname{IgA}$ の腸管吸収は認められな かった。

1 日齢マウスに経鼻接種すると, 免疫マウス由来の場 合に全く死亡例はなく, 抗体の上昇もなく, CF 抗体の 上昇屯なく, 高度な受身免疫が獲得されたいた。非免疫 対照群での LD50 は103EID50 量で, 生存マウスでの明 らかな抗体上昇があった。

接触感染後の抗体上昇を指標とする場合, 免疫親マウ スよりの，3，4，5，6，7 週齢マウスであ, 対照マ ウス群の場合と同程度の抗体産生がみられ, 移行残存抗 体による感染防禦作用はみられなかった。

考察 :

われわれの SPF マウスでの接触感染実験の結果は, 感染マウス鼻口腔内 “Shedding virus” の直接的伝播が, 自然界での感染の成立に大きな役割を演じているもので あろうととを示すあのであったが，過去の幾つかの報告 より, air-born infection, 実験者または器物による媒 介による場合のあることあ十分に考えられる。

Robinson 等 (1968), Appell (1971), また, 上述の 実験結果は, HVJ のマウス肺内増殖は比較的短時間で, 感染10日目には検出不能になることを示めしている，コ ロニ一内持続感染の原因をマウス個体内持続感染性に擬 することは無理の如くに思われる。

移行抗体は新生マウスに強度な免疫抵抗性を賦与して いるが，持続性が短く，離乳期には消滅しており，それ らマウスは接触感染に対し高い感受性を有するに至って いる。われわれはウイルス分離試験を行わなかったが， 福見等(1962), Parker 等 (1964) は, HVJ 分離成功例 は21〜38日秢のマウスの場合に高いことを述べてい，乙 れらの点から，コロニー内におけるかかる感受性個体の 持続的存在が HVJ 感染の持続性に一きな役割を持って いるであろうことが考察される。

\section{4. マウス生産コロニーの污染}

\section{藤 原 公 策 (東大医科研)}

マウスコロニーにおけるセンダイウイルスの污染につ いては数多くの報告があるが，最近では Fnkumi[5]の 報告にあるような epizootic type の感染はむしろまれ で, enzootic typeの污染がみられることが多く, adult 個体の抗体陽性率は70\%以上亿達しながら発病する動物 がほとんどみられないととが多い。このような污染コロ ニ一内でのウイルス伝播は air-born よりむしろ直接の contact infection が重要であることも指摘されて, enzootic type の infection では, 離乳直後のマウスに一 過性に急性感染がおこり, virus が散布されるといわ れ，実験的うらづけあえられている。しかし，実験的 に污染コロニーマウス間で, どのようにウイルスの伝播 
がおこっているかについては，な纬証を欠く面ああ る。一方, 肝炎ウイルスについては, 粪便中渄出され るウイルスが感染源となることを示唆する Rowe らの 報告および幼若マウスで経鼻感染が成立しやすいとい う Gledhill らり報告があるが，マウスコロニーにおけ るウイルスの動態てついては，ほとんどわかっていな い。われわれは，1970年 4 月〜1973年 3 月の間に，28J 生産コロニーおよび実験コロニーについて各種病源体に よる污染の有無を検索したが，たまたまその中の 1 生産 コロニーでセンダイウイルスの enzootic な污染が検出 された。そこで, この污染コロニーに打ける両ウイルス の動態を知るために, 污染生産コロニーマウスと非污染 コロニーマウスを組合わせて， $2 ， 3$ の実験を行い，次 のような成績をえた。

比較的大規模の 1 マウス生産コロニーにおいて，1年 8 力月にわたって adult マウスのセンダイウイルス, マ ウス肝炎 $(\mathrm{MH})$ ウイルスの $\mathrm{CF}$ 抗体をしらべたところ センダィウイルスについては，48１00\%，MH ウイル スについては64〜93\%の抗体陽性率をしめした。このコ ロニーの 3 週齢マウスの, 約 $80 \%$ は抗センダイウイルス 抗体を保有していたが，4 週齢マウスのほとんどでは， 抗体が検出されなかった。しかし6週㱓以上のマウスで は, 成熟マウスと同様, 高率に抗体が検出された。同じ マウスについてしらべた抗MH マウス抗体は，3 および 4 週龄では全部陰性であったが，6週㱓では $44 \% ， 8$ 週 踰では54\%が陰性であった。

同居させた清浄コロニー由来感受性マウスの抗体陽転 によってみると, 污染コロニーでは 4 週龄マウスはセン ダイウイルスを保有せず，移行抗体価の低下した 6 週籿 マウスが, ウイルスの増幅, 伝播主役を演じているこ とが明らかにされた。これに反して，MH ウイルスに関 しては，非同居の対照マウスにも一部陽転例があり，お そらく air-born の感染がおこったと思われるが，污染 コロニー由来の 4 週齢マウスと同居したものの陽性率は これより高かった。污染コロニー由来り $6 〜 10$ 週齢マウ スとの同居によっても, 拈とりマウスの一部が陽性とな った。

以上の成績から大規模の污染マウス生産コロニーでの センダイウイルスの増幅伝播は，6週間前後の育成マウ スを中心に扢こっており，離乳直後の若いマウスおよび 成熟動物では受動あるいは能動免疫が成立していて, ウ イルスの増幅伝播者とはならないらしいことがわかった

\section{5. ラット生産コロニーの污染}

牧野進（シオノギ油日ラボラトリーズ）

センダイウイルスの流行の生態を規模の異なる 2 力所 のラット繁殖集団でくわしく調べてみたととろ, ウイル
スの流行に異なった様態がみられるという興味深い知見 が得られた。ラット生産コロニーの污染の実状の一端を 報告する意味で, 私共の体験した同ウイルスの流行の特

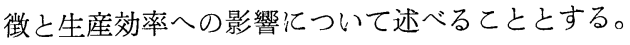

調查対象とした集団は, 系統育成を主目的としている $\mathrm{A}$ c, 生産場の一室である Bであり, その集団の大きさ は前者が約500匹，後者が約 1,000 匹である。ただし，B のある生産場全体では約11,000匹の動物が常に飼育され ている。Aでは毎月約17匹が交配されているが，それは 規則的なあのではない。Bでは毎週約70匹が規則的に交 配され，350匹が離乳している。 $\mathrm{A}, \mathrm{B}$ とあに通常環境下 であるが，Aでは外部から搬入する床敷, 衣服等は蒸気 滅菌して用いている。Bの飼育者は生産場内での交流は 自由であったが，Aとの交流は全くなかった。AとBの 距離は約 $20 \mathrm{~m}$ である。

ウイルスの抗体検査は HI 試験によった。個体別に採 取した血清は RDE(Recepter Destroying Enzyme) 処 理で血球凝集抑制因子を除去し，さらに20\%鷂血球浮遊 液で非特異的凝集素を吸収除去した。抗原には発育鶏卵 で継代したセンダイウイルスZ株をエーテルで不活化し たものを用いた。ウイルスの検索は肺を PBS で10\%乳 剂にし，1,000rpm， 6'遠心し，上清 $0.2 \mathrm{~m} \ell$ を 3 ケの 8 日卵に接種し, $37^{\circ} \mathrm{C} 3$ 日間培養後, 漿尿液の鶏血球凝集 性により判定した。初回に陰性のものはさらに羊膜およ び漿尿膜の乳剂を8 日卵に接種し, 全例の漿尿液が $\mathrm{HA}$ 性を示さない場合, はじめてウイルス陰性とした。

はじめに小集団であるAの状態から説明する。Aには 19o1年に BS 動物が導入されたが，初期の 4 年間は呼吸 器病の発生をみなかった。しかし，'66 年にスナッフル を主徴とする呼吸器病の流行をみとめてから毎年発生を みとめ, '67年から'70年までの 3 年間に 7 回の発生をみ とめた。そのうち 4 回は規模の大きいあのであった。流 行は長い場合でも約 4 週の経過で終息した。流行間隔は 最短 2 週, 最長 1 年であった。集団内での流行の伝播は 急速で，いずれの流行でも少数の発病ラットが発見され るとほぼ数日で全体に広がった。これらの呼吸器病の病 原を調べるため'68 年からセンダイウイルスの検索を実 施した。 2 年間に亘る調査で 3 回の流行がみとめられ た。いずれの流行時にあ血球凝集性ウイルスが分離さ れ，しか屯 HI 抗体は流行後陽転した。しかし，流行消 退後はウイルスは一度あ分離されなかった。'68 年の夏 の流行が終ってからは, 流行後に生まれた動物には抗体 はみとめられず，翌年の 9 月の発生時まで集団内では抗 体陽性ラットと陰性ラットが日粭で区別出来た。因みに 9 月の発生前の集団内の陰性ラットと陽性ラットの比率 は9:1であった。'68 年の夏の流行で獲得した親の抗 体は翌年の 4 月頃まで高く，その後徐々に低下した。初 
回に分離したウイルスの性状をセンダイウイルス伏見株 と比較したところ, 熱抵抗性 $\left(50^{\circ}, 5\right.$ 分), 中和試験, $\mathrm{HI}$ 試験では同一であった。さらに分離したウイルスを ラット，マウスに経鼻感染させたところ。いずれにあ流 行時と同じ呼吸器症状がみとめられた。したがって, 私 共は Aでくり返し発生した呼吸器病はセンダイウイルス に起因したと考えている。

流行時の観察所見では幼若動物の発育不良, 離乳率の 低下, 肺の肝様変化が著明であった。'66 年以降の大規 模な流行時では, いずれも繁殖効率への影響は大きいむ のであったが，'68 年の夏の流行時だけは影響を受けな かった。

以上述べたように，Aではセンダイウイルスの爆発的 な流行が観察されたが，てれらの流行様態がラット集団 の本質的なものなのか，それとも集団の大きさ関係が あるのかを明らかにするため， Bでの流行状態を 1 年間 調べてみた。その結果, BではAでみられたような流行 は一度あ発生しなかった。 HI 抗体の月別分布をみても 抗体陰性加ら $1: 512$ 以上の高い抗体価を示すあのまで 段階的な分布がみられ，しかもこの分布状態は一年を通 じほぼ同一であった。肺の剖検所見であ大流行を示唆す るところはなく，非常に低率であったが，いずれの月屯 異常所見がみとめられた。スナッフルをみとめ殺処分し た動物数も肺の所見と同様に少数であったがほぼ毎月み られた。離乳率はいずれの月すほぼ80\%以上の成績を示 し, 安定した状態であった。これらのととから，Bでは ウイルスの大流行は発生しないかわりに，小流行はとぎ れることなく部屋のどてかで発生していることが推察さ れる。

以上私共の関係しているラット集団でみられた流行例 について述べた。ラット集団の污染を検出する場合, 集 団の大きさ，検査する動物の日路等を考慮する必要があ ると思われる。センダイウイルスの污染のある集団で生 産効率への影響を調べる場合には, ウイルス流行の生態 の如何によってその影響に差異のあるととを，併せて考 える必要がある。

\section{まとめ}

藤 原 公 策 (東大医科研)
中 川 雅 郎 (予研)

本日のシンポジウムの内容は次のようにまとめられよ う。

ネズミコリネ菌については, 污染の検査法として, 血
清反応による診断，菌の分離あるいはコーチゾン接種に よる病変の誘発試験が現在広く使われている。このうち 凝集抗体の検出による方法が，特異性の上からああるい は術式の簡便さからあ，あっとあ有効な手段であると考 えられる。しかし，血清反応だけにたよっていたのでは 污染の摘発が後手後手にまわるおそれああり，一方では 英国の MRC の規準では本菌の検査にマウス咽頭部から の菌分離法が採用され，わが国においても，腸管からの 菌分離が污染の摘発に有用であるとする報告あある。そ こで, ネズミコリネ菌の污染の検出のためには, 咽頭部 あるいはは腸管からの菌分離と凝集抗体の検索をあわせ 行なうことを検査のたてまえとするととにしたい。分離 菌の同定についても血清反応を応用すれば効果的であろ う。コーチゾンによる誘発試験は環境の污染をむたらす 危険性があるので, 血清診断によって污染の疑いが濃厚 な場合とれを確認するなど，特殊な目的以外には避ける べきであろう。

センダイウイルスについては，すでに1962年，東北大 学石田教授を中心に, ウイルス学の専門家によって, ほぼ完璧と思われる検査基準が作られており（実験動 物，11，128，1962)，乙の基準には, 検査法の詳細はも ちろんのとと, 検查成績の通報手績きや，検査料金にま であ言及してある。したがっててれ沉つ加えるべきて とは少ない。ただ污染コロニーにおける垂直感染の様式 にかんがみて，検查対象の動物の age についてはしかる べき配慮が必要であろう。また生産コロニーでのセンダ イウイルス污染の多くは, enzootic type であり, 高い 抗体陽性率が維持される。乙れに反して, ウイルス分離, 抗原の検出が可能なのは一定の時期, 年齢にかぎられる ようであるから, むしろこれを従とし, 抗体検出の方を 主とすべきであろう。ウイルス分離にはネズミコリネ菌 の場合と違ってかなりの経験と熟練を必要とする。発病 個体ではパラフィン切片による蛍光抗体法によって容易 に気管支上皮のウイルス抗原が検出されるのでこの方法 の併用も可能であろう。

本日の討論の中にああったように，センダイウイルス はマウスやラットだけではなく，他の動物種にあ広く分 布するあのであるから，乙のととを考虑した広範囲な疫 学的検討が今後必要で, その結果にもとづいて実験動物 コロニーの污染防止の方策がたてられなければならな い。

以上が本日のシンポジゥムの司会者としてのまとめで あるが, 提示された検査法について, 会員各位の積極的 なご意見が寄せられることを期待してやまない。 


\section{シンポジゥム $\mathrm{B}$ \\ ヒトのモデルとしてのサル類の有効性とその限界}

\section{第 1 部 サルをモデルとして使っている立場 から}

\section{1. 内分泌之代謝}

大 沢 仲炤 (東大医学部第三内科)

サル（ここでは Macaca 属のサルをさす）を含めて各 種の動物をヒトのモデルとして実験に用いる場合に，そ の成績がヒトに外插されるととが重要である。そのため には，進化の過程において，サルがヒトのモデルとして どのような位置におかれるかを知る必要がある。乙の際 ホルモンは，その優れた定量性の故に，その有力な指標 の一つとなることができる。

サルがヒトのモデルとしてどのような有効性と限界を 有するかを内分泌之代謝の面から検討し

1）サルでなければならない研究

2) サルでなくてもよい研究

3）サルでは不可の研究

a） サルでも不可の研究

b） サル以外で適した動物のある研究 について例をあげて説明する。

1）サルでなくてはならない研究

この分野の研究としては, 月経周期汇伴うホルモン, すなわちLH, FSH，エストロゲン，プロゲステロンの 変動があげられる。ヒトの月経周期においては, 最初に 中間期のエストロゲンのピークが出現し,ついで LHお よび FSH のピークが出現, その後に排卵がおこると共 にプロゲステロンの黄体期の増加がみられる。この動態 を完全にシミュレーションするのはサルのみである。ま た下垂体性成長ホルモンの免疫学的活性, および生物活 性とあ，ヒトとサルにおいてのみ共通している。したが ってその研究にはサルが適している。副腎皮質から多く の種類のステロイドホルモンが分泌されているが，その うち副精性男性ホルモンの種類には著明な動物種差があ る。特にデヒドロエピアンドロステロン硫酸エステルは ヒトに扔いて最あ大量に分泌されるホルモンであるが， これを分泌するのはサルのみであり，したがっててのホ ルモンは霊長類に特有なホルモンといえよう。

ニホンザルのメスは夏季に不婎状態になるが，この際 女性ホルモンを分析すると極めて低值となり，且つ月経
周期に伴う変動を示さない。この状態はヒト第二度の不 妊症のモデルとして優れたあのである。

2）サルでなくても可能な研究

これは，サル以外の入手容易な動物でむ行える種類の 研究であって, 例えば, 下垂体副腎皮質系, 下垂体甲状 腺系，下垂体性腺系などのホルモンのフィードバック機 構による調節の問題があげられる。乙れらはラットにお いても十分任究が行える。また血中の副腎皮質ホルモ ンはいわゆるエピーソード的分泌機構により著明な律動 的変動を示すが，乙れはサルのほかウシにおいても十分 に認められる。このように，生体つ基本的機構そのあの に関する研究としてはサルを用いないですむすのが数多 くみられる。

3. サルでは不可の研究

これには，a）サルを含めてすべての動物で不可の場合 と，b)サルでは不可であるが他の動物では可の場合とが ある。

a） サルでも不可の研究

この分野としては，ヒトに打いて始めて獲得された醉 素活性の増加の例がある。例えばステロイド16位水酸化 酵素活性は，類人猿以上に扔いて著明となるために，エ ストロゲンの主要代謝産物はエストリオールであるが， サル以下の動物ではエストロンである。また妊娠時の女 性ホルモン，すなわちエストロゲン，プロゲステロンの 動態むヒトとサルでは極めて異っている。すなわちヒト では，両ホルモンは妊娠と共に急速な増加を示すが，サ ル以下の動物では著明な増加を認めない。これは胎児胎 盤系の機能が両者の間で極めて異っていることを示して いる。したがってサルとヒトの妊娠時のホルモンの問題 に用いる場合には慎重な注意を必要とする。

b） サル以外で適した動物のある研究

この例としては, 脂質代謝, 殊に動脉硬化症の研究が あげられる。この研究にはサルよりあむしろマーモセッ ト，ブタがヒトのモデルとして適しているととが知られ ている。

以上を総括すると，1)の項目，すなわちサルでなけれ ばならない研究はサルの有用性を示すものであり，3)の 項目，すなわちサルでは不可の研究はサルの限界を示す あのと考えられる。との点が更に明確になるためには今 
後多くの研究がなされなけ机ばならないが，内分泌，代 謝の研究面を検討すると，サルを絶対必要之する研究は 必ずしも多くないのに注目される。

\section{2. 毒性実験におけるサル類の有効性と限界性につい $\tau$}

松島 松睟·阿部栄四郎（日本農村䀢学研）

\section{1. 諸言}

われわれの研究所においては, 1966年以来農薬の毒性 実験のために, サル類を多く使用してきた。その最む大 きな理由は, 従来の毒性実験が主としてマウス, ラット という小動物に限られていたため，どうしてもより人に 近いサル類に打ける毒性実験む必要だと感じたというこ と，それから農薬においては神経系に障害を与えるもの が多いが，その障害の観察にサル類がより適当であろう と考えたからである。しかし 8 年間のわれわれの経験か らみた結果では，毒性実験におけるサル類の使用は，あ る面では有利であるが，ある面では不利な点も有してい る。以下，その点について若干の経験を述へてみたい。

\section{2. 研究成績}

1）現在までの購入内訳と検疫状況

われわれが1966年以来購入したサルは，全部で 132 頭 であり，種別にみるとアカゲザル97頭，カニクイザル 35 頭である。産地は, パングラディシュ, インドネシア， フィリッピン，インド，中国等に及ぶ。一部日本モンキ 一七ンターや静岡県実験動物農協で予供飼育したものも 含まれているが，大部分は羽田経由直送のものである。 われわれが行なっている検疫方法は, 結核ツベルクリン 反応之粪便の赤莉菌培養である。過去任購入したあのの 中，いずれあ陽性を示すあのはなかった。糞便の虫卵検 査は一部にしか行なっていないが，陽性率は78\%で比較 的多い。陽性の屯のに対してはサイベンゾールで駆虫を 行なった。

\section{2）飼育条件とサル死亡数}

購入したサルは， 3 カ月乃至 6 力月予備飼育した後に 実験に供している。飼育室は, 温度 $25^{\circ} \pm 1^{\circ} \mathrm{C}$, 湿度 $55 \%$ $\pm 5 \%$ あ゙あ。ケージは個別ケージ，飼料はサル用固形 飼料（船橋農場製）を用いた。死亡したサルは，132 頭 中14頭であるが，ての中予備飼育中の死亡11頭，実験中 死亡 3 頭である。事故死およびストマイ注射によるショ ック死を除くと, 自然整死とみられるもの 4 頭 $(4 \%)$ で，比較的少ない。

\section{3）毒性実験の概要}

全部が農楽で, 殺菌剂の酷酸フェニール水銀 $(\mathrm{PMA})$, 塩化エチル水銀 (EMC), 有機燐殺虫剂の Malathion, Sumithion，DDVP などであるが，いずれあ亜急性あ るいは慢性実験が多い。
4）毒性実験に扣ける諸問題

a. 年齢（体重）および遺伝体質について

サルが現地で手当り次第補獲され，野生状態のまま羽 田江直送され，直ち亿実験任供される点を考えると，遺 伝体質的な均一性は全く得引れない。また毒性実験には 多くの個体数が必要なわけであるが，サル類は，その供 給源の困難さはもとより, 動物自体大きく，その飼育管 理には，一定の体力と技術を必要とし，また費用の点か らも, この要求に応じられないのが実状である。また限 られた数の中でも, 性別, 年秢（体重）等においても仲 々均一なあのが得られない。

b. 薬物投与法について

飼料添加, ネラトンカテーテルによる強制経口投与, バナナに注入しての投与を行なった。飼料添加は，とく に長期連続試験汇有利であり, また農薬等, 食品残留性 が考えられるものに扔いては目的に適っているが，サル は餌をかなりこぼすために，摂飼量の測定が不正確とな り, 正確な薬物摄取量が計算できないとと, また薬物に よっては分解しやすいあのがあるため, 長期の保存が無 理なととにより, 適当ではない。次にネラトンによる強 制経口投与は，急性実験ならば問題ないが，長期間毎日 投与するこ之は，労力的にみても困難である。そこでわ れわれが考え出したのは，バナナに添加したり，注入し て投与する方法である。乙れは投与量が少ないとき $(0.01 \mathrm{~m} \ell / \mathrm{kg}$ 程度) には非常に簡単で確実であるが，投 与量が多かったり，特異な臭気と刺激を持っているあの (PMA，EMC など）の場合は，必ずしもうまくいかな い場合あある。

c. 一般検查扔よび病理組織検査について

毒性試験汇おいて一般的汇行われている検尿, 血液一 般検查, 血液生化学検查, 病理組織学的検查等を行なっ ているが，検査それ自体はとくに問題ない。しかし均一 な個体が得られないいめに，検査值任個体差が大きいこ と，年齢が一定しないために，年齢によって差が生ずる 検查值（例えば ALP など）の場合注対照群之の比較が 困難であるとと，また寄生虫その他の感染も多く，臟器 への寄生も多いので, 病理組織学的な判定も困難である ことなど大きな問題がある。サル類はある種の薬物に対 しては，マウス，ラットより感受性が高く，ヒトに近い と考えられる面があり，とくに有機燐の実験汇関して測 定を要する血清抢よび血球コリンエステラーゼ值は，最 も七トに近い值を示して有効である。

d. 生理学的検査について

サル類は, 生理学的検査とくに神経学的検査に执いて 他の小動物より有利である。われわれは，有機燐の毒性 実験において, 眼科学的検查㧍よび脳波学的検查を行な っているが，脳はよく発達していてヒトに似て扔り，特 
に皮質などの新しい部分の発達が他の動物に比べてヒト の脳により近い状態となっている点, また眼科学的に は, サル類はヒトと同様両眼が正面を向いて抢り, 瞳 孔, 角膜等の検查も全くヒトと同様化行うことができる し, 眼底像屯やや色素が多いが人間つ場合と全く同一で ある点など, 有用性が高い。しかし慢性実験における頭 皮上脳波測定は, 筋電図混入のため著しく困難であるし, また眼屈折, 角膜曲率半径測定などは, 動物の視線を固 定できないため，なかなか客観的数值が得られない。

\section{3. 考察}

以上のでとく, サル類は毒性実験における対象動物と して, 種々な点で有用性もあるし, また問題点も有して いる。これらの利点, 欠点を充分認識した上で, サル類 を使用していくべきであるが，今後毒性実験の上では， あっ之生理学的な変化, とくに神経生理学的な変化の追 究に利用されなければならないと考える。

\section{3. ウイルス感染}

山 内 - 也 (国立予研)

サルは実験動物の中で，あっとあヒトに近い性質を備 えていてヒトの多くのウイルスに対しても高い感受性を あっていることから, ウイルス感染症の研究にサルが重 要な実験動物であること虫いうまでもないが，実際には サルを用いたウイルス感染症の研究はマウスのような地 の実験動物の場合と比べて，あまり広くは行なわれてい ない。この理由としては, サルの実験動物としての品質 の不均一なとと，実験に要する人手，経費の点などが関 係しているあのと考えられる。また，乙れまでウイルス 感染症の研究の多くが， ウイルス側江重点を打いて来て いたため，無理にサルを実験動物として用いなくてもウ イルスに感受性のある組織培養や，マウスのような確立 された実験動物で充分に用の足りたこと屯, サルの需要 が一部の研究に限られていたととの理由の 1 つと考えら れる。

しかし, 最近, ウイルス感染症の研究面で, ウイルス 側の要因だけでなく，宿主の側の要因が重要視されるよ うになって来ており，実験動物の系で成る可くヒトの場 合に類似した症状を再現させる必要が超きて来て, サル を用いた感染実験の重要性が増して来ている。

以下, ウイルス学研究分野におけるサルの利用状況と 問題点を簡単に紹介する。

(1) ウイルス感染症の発苪機序の研究モデルとしての サル

この種の研究はサルでなければヒトの場合に類似し た疾患を再現できないウイルスについて主に行なわれて いる。サルでヒトの病気とほとんど同様の症状を再現で きる代表的な例としては黄熱があげられる。しかし，多
くのウイルス感染症では, サルでヒトの病気を再現する ことは必らずしも容易ではない。麻疹に例をとってみる 之, 麻疹ウイルスに感受性をむつ実験動物は特殊な感染 形式の研究を除けばサルに限られているが，サルで実験 的に再現できるのはリンパ組織病変と免疫反応であっ て, 発疹, 発熱などの全身症状の再現, 麻疹脳炎, 巨細 胞肺炎のような合併症はかなり困難である。しかし，乙 れらの各種症状の発生機序には生体側の要因, とくに免 疫反応が重要な役割を果たしていると考えられるので, 成る可くヒトに類似した生体反応を実験的に再現させる ためには，やはり，サルに頼らざるを得ない。少なくと も組織病変のレベルでは麻疹の再現は可能なととから, 症状のみでなく組織学的検討, より一層感受性の高いサ ルの種類の検討などを更に進めるととにより，モデル実 験系を作ることは可能と考えられる。

また，通常のウイルス感染症だけでなく，スローウイ ルス感染症の研究分野であサルは実験動物として極めて 重要な地位を占めている。麻疹ウイルスの脳内持続感染 による亜急性硬化全脳炎 (SSPE), クル (kuru), ク口 イッフェルトーヤコブ病などでもサルが用いられてお り, この中, 後 2 者ではチンパンジーなどで感染実験が 成功している。

通常のウイルス感染症, スローウイルス感染症の研究 いず机狲いてあ問題点としては, サルについての免疫 学的基礎データの不充分なととがあげられる。発病機序 に生体の要因として免疫の関与が強く考えられることか ら, この面での基礎データの蓄積が要望される。

(2) 生ウイルス・ワクチンの検定に扔けるサルの利用 生ウイルス，ワクチンの弱毒性を確認するととは，ワ クチンの安全性を保つためにあっとも重要な点である。 実際に, ワクチンの開発段階では, サルでの反応性が確 認されてから人体接種に踏み切ることになっており，ま た市販ワクチンの品質管理の面でも, 各ワクチンロット が常に一定レベルの弱毒性を保っているととを確かめる ために，ワクチンの検定にサル接種試験がとりいれてい る。

現行のワクチンについては, 生ポリオワクチンで脳内 之脊髄内接種試験による神経毒力の推定, 生麻疹ワクチ ンで脳内接種試験による神経毒力的推定と皮下接種試験 による弱毒確認 (リンパ組織病変の程度と接触感染性の 有無から判定）が行なわれている。また，近く市販され る予定の生風疹ワクチンでもサルの脸内接種武験がとり いれられている。

このようなサルにおけるテストはヒトでの病原性をあ る程度までは推定している屯のとみなせるが, 未知の点 あ多く, ワクチンの弱毒性は究極的にはヒトでなりれば 判らないといった議論も当然ありうる。しかし, ヒトで 
は実験できない以上, やはりワクチンの弱毒確認はサル にかなり頼らなければならないであろう。そのために， 今後, 前項に述べたウイルス感染症の発病機序の研究の 実際的応用として, ワクチンの弱毒確認, 副作用の発現 機序について更に研究を進める必要がある。

(3) ヒトの腫湯の研究モデルとしてのサル

サルと関係のあ腫痬ウイルスは(1)サル以外の動物由来 でサルに腫瘍をつくるもの，(2)サル由来でサルに腫瘍を つくるあの，(3)サル由来でサルには腫痬をつくらず，他 の動物に腫痬をつくるもの, の 3 つに大別される。(1)と してはラウス肉腫ウイルス，ネコ肉腫ウイルス，(2)では ヘルペス・サイミリ, ヘルペス, アティーリス, M-P

乳癌ウイルス, ギボンC型ウイルス, シミアン肉腫ウイ ルスなど，(3)にはシミアン，アデノウイルス，SV40な どが属している。

これらの中, (2)のグループについての研究が最近あっ とあ重要視されて来ている。とくに 2 株のヘルペス, ウ イルスについてはヒトのバーキットリンパ腫との比較が 念頭におかれて研究が連められている。

サルを用いたこれらの腫瘍ウイルスの研究は現時点で は詳細な解析の面ではマウス白血病ウイルスやニワトリ 白血病ウイルスの研究レベルには達していないが, サル がヒトに近いという点から, 将来, ヒトの癌の原因の解 明, 予防, 治療に果たす役割は大きい屯の之期待され る。

(4) サルにおけるウイルス污染

この問題は直接, 本論とは関係ないが, サルを扱う以 上, 極めて重要な問題であるため, 簡単に触れておく。 ここで関係のあるウイルスは污染経路から次の 3 つに 分類するととができる。(1)サル $\rightarrow$ サト，(2)ヒトーサル， (3)動物（サルを含む） $\rightarrow$ サル。

(1)ではBウイルス，マールブルグウイルスが代表的で あり, その他, モンキーポックス, ヤバウイルス, タナ ポックス, シミアンウイルス (75種類) がこのグループ に入るあのと思われる。(2)では麻疹が代表的であるが， 抗体調査やウイルス分離の成績からヒトのウイルスの大 部分がこのグループに入る可能性をあつと考えられる。 (3)ではアルボ・ウイルス, とくに黄熱, キャサヌル森林 病ウイルスがあっとも注意を要する。他に, 狂犬病ウイ ルス, ヘルペスウイルス群（タマリヌス, サイミリ，ア ティーリス）などもこれに属する。

\section{4. 菌科の領域}

\section{五 嶋 秀 男 (城西歯大)}

歯科の領域で，サルを実験動物として用いた研究はま ださほど多くない。ヒトもサルも歯はエネメル質・象牙 質・セメント質の 3 つの硬組織の中に歯䯣という軟組織
を入れ，粜根膜によって雬槽に結びついていて，骨とは かなり違った構造をしている。また乳歯の歯根吸収と脱 落に引き続いて代生歯（二生歯性）である永久歯と交換 するという他の臟器にみられない特異な器官であある。 従来, 乳雨根の吸収や歯の交換などの研究は, イヌが多 く使われてきたが, 歯の形のちがいからいうと, サルの 方がはるかにヒトに似ている。そこで歯の発生, 乳歯の 萠出・脱落, 永久歯の萠出の過程をスライド写真で, ヒ トと対比しながらサルについて述べ，その他 $2 \cdot 3$ の問 題にふれてみたいと思う。

\section{I 歯帯孔について}

\section{A さらした鿒骨の観察}

ヒトの乳歯をむった顎骨を観察すると，上㜔では乳中 切歯· 乳側切歯· 乳犬歯, 下顎では乳中切歯· 乳側切歯 ·乳犬歯·第 1 乳臼歯の舌側に小孔がみられる。これが 歯帯孔である。この小孔は，一見他に存在する栄養孔之 区別しにくいものああるので，歯の発育に必要な血管の 通路であるとする説もある。しかしての小孔を何が通る かは，さらした骨の表面からの観察だけでは説明されな いので, 組織標本で後述するとしても，乙の小孔から後 続の永久歯の尖端がのぞいており，しかも䞄骨の発育す なわち永久歯の萠出の順序にしたがって, 乳歯側, すな わち外側に向って大きくなり，ついには乳歯歯槽の内縁 と合体し，更に乳歯が脱落し，3者が一緒になって生じ た大きな孔より，後続永久歯の萠出するととから，歯の 萠出に関係のあることをうかがい知ることができる。乙 の歯帯孔は, サルのさらした顎骨にあみられ，ヒトと比 較してサルの方が 1)歯帯孔の位置は正確であり，2)孔 の大きさの変化も発育の順序にしたがって大きくなり, 3) その形む正円に近い。

\section{B 組織標本の観察}

1)サルの上下顎の乳中切歯, 乳側切歯, 乳犬歯および 下○第 1 乳白歯の舌側にみられる小孔は，後続歯の歯胚 と達する歯堤の通路で, さらした骨にみられた歯帯孔に 一致する。しかもこの小孔内には顎骨や䨑胚の発育に必 要と思われるような血管はみられなかった。2)後続歯の 原基は, 乳歯の舌側で, 乳歯歯槽の入口近くに位置す る。しかし胎生末期になると隣接する乳歯根との間汇薄 い骨性の中隔が生じ, 乳歯根と隔てられる。3)顎骨の形 成は，口腔粘膜に向って伸び，後続歯の歯胚は骨質で囲 まれ，骨包が形成される。しかし骨包上壁に歯堤の通る 孔一歯帯孔があり，乙れを通じて骨包内腔は，口腔粘膜 下組織と連絡する。乙の歯帯孔の周刃，とくに乳歯根側 にある骨質は破壊吸収され，ついに乳歯歯槽之合体し単 一腔となり, ついで乳歯が脱落して後続雬の萠出を促 す。4)下顎第 2 乳臼歯, 上顎第 1 , 第 2 乳臼歯の歯胚に 対しても，それぞれ歯帯の通路があるが，乙れらは前歯 
部および下顎第 1 乳白歯のように舌側開口しないで, 歯根の分岐部に口を開くので, 表面からみるととはでき ない。これら隠れた歯帯孔は, 細長く歯帯管をつくり， しばしば屈曲を示す。5)以上のように歯帯孔の組織学的 検索には, 乳幼児の死体の入手困難加ら，ヒトに最も近 いサルを用いるほかは全く不可能といってもよいと思 う。

\section{II 歯䯣の感染実験について}

歯が触蝕になると歯䯣を刺激して疼痛を感ずるように なる。更に被蝕が進行すると, 歯䯣は感染し, やがて壊 死に陥いり，炎症は歯の支持組織におよび，慢性に経過 すると歯根の尖端に病巣をつくる。乙れがいわゆる根尖 病巣である。乳白歯の場合は下に永久歯胚を抱き込んで いるので, 歯根は永久田歯より拡がっているが, 病巣は 永久臼歯の場合の上うに根尖孔京中心して丸くできな いで, 歯根の搪がりにしたがって根分岐部に形成され る。このととはいろいろに言われているが実験的に解明 されていない。そてでヒトに最もよく似たサルの歯で歯 葡腔を開放して自然感染したものと, Staphy lococcus aureus $209 \mathrm{P}$ 株で感染させた実験を試みた。

A 自然感染させた実験

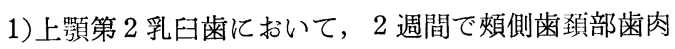
飞発赤・腫脹を認め, 13 週で根分岐部歯肉飞大豆大の膿 瘍を作り，15週で小指頭大となった。2)下顎第 1 乳田歯 に扔いて，5 週で根分岐歯肉に小豆大の発赤・腫脹を 認め, 9 週で瘻孔を作り, 19週後顎下部仁小指頭大の外 歯瘦を形成するに至った。

B S. aureus 209 P 株感染実験

1)下顎第 2 乳白歯に扔いて，第 2 週で歯頝部歯肉に小 豆大膿瘍を認め，9週で瘦孔が生じた。2) 5 週間で右眼 瞼内角の直下にウズラ卵大の腫脹をともなった外歯瘦を 形成した。

\section{III 歯科矯正の立場より}

歯科矯正学的実験上用いられる動物は, イヌ, ラット が多い。しかし咬合関係などを考慮するとサルが最適と 思われる。そこで矯正治療上しばしば行なわれる歯の便 宜抜去後の施術開始の時期などについて，サルを用いて 興味ある知見を得た。1)従来便宜抜去した場合, 歯の移 動開始は, 相当日数を経ななければならないと考えられ ていたが，抜歯後 3 日一 7 日に移動開始した方が 21 日一 28日のものより移動距離が大きく，しかあ抜歯窩の治瘾 の阻害は認められない。2)移動開始時期の早い屯のの方 が Precementum による修復が観察される。また old bone を伴った移動像が見られる。（この頃岐阜歯大・ 丹羽金一郎)

IV 以上のととがらから，ヒトのモデルとしてのサルの 限界性については, な拸くの実験の積み重ねを必要と
するが，有効性については期待するとてろが大きい。

\section{5. 新生児学の基礎としてのサル類での実験的研究の 状況}

$$
\text { 杉 浦 寿 康 (名古屋市立大学·医·小児科) }
$$

Barcroft にはじまり Dawes，Barron，Plentl, Assali らにより, 胎児, 新生児の生理学的研究は, 最近の 30 年 間隐速な発展を遂げて来た。しかし，てれまでの研究 の多くは，緬羊の胎児を，主たる実験動物として用いて なされたあのである。

われわれが，ヒト（人間の胎児，新生児）のモデルと して, いかにサル類に期待し, また必要としているか を，ご理解いただくためには，まず，今日における医学 上の問題点を少し述べてみたい。すなわち，1）分婏障害 に基づく酸素欠乏之脳損傷，2)頭蓋内出血の成因拈よび その予防之治療, 3)特発性呼吸窮迫候群の予防之治療,

4)酸素の毒性，5)核黄瘠，その予防としての光療法とビ リルビン代謝，6)低血糖症と脳障害，7)その他。以上の 諸問題は，いずれあ脳障害に結びつくあのである。折角 救命し得て屯, 中枢神経系の障害（例, 脳性麻痺）を遺 しては，その児は，一生不幸を背負って生きなければな らず，われわれは，乙のような不幸な児を 1 人であ少く しょうと努力しているのである。究極的には中枢神経系 の病態生理学的解明, 中枢神経の障害発生の機序の解明 が必要となるわけで, 形態的, 機能的にヒトの中枢神経 と最も類似点の多いサルが，実験動物として必要とされ るのである。

ヒトのモデルとして使用する以上，できるだけヒトと 類似していた方がよい。胎児の発育についてみると, 胎 児重量の増加率をみると, アカゲザルはヒトと全く一致 している。他のブタ，ヒッジ，マウス等は，ヒトとかな り異っている。母体重に対する新生児（仔）体重の割合 は，ヒトが5.7\%，ヒッジ $5.7 \%$ ，アカゲザル $6.3 \%$ よ く似た值である。しかしヒッジは通常双胎であり, 後述 するように胎盤む異なっている。アカゲザルは単胎であ り，妊娠期間はヒトの 280 日にはおよばないが，ヒッジ の147日に比へ，168日である。新生哺乳動物の諸蔵器の 重量を体重比でみると(表 1), 脳, 肝蔵, 心において, ヒトとアカゲザルは一致しており, 肺む両者でよく類似 している。ヒッジでは, 肺のみヒトと同じ值を示すす。 胎児胎盤の重量比は, ヒトとブタ, ネコが一致するが, ヒトの14\%に対し、アカゲザルは20\%である。しかし， 胎盤の組織学的分類は（表 2 ），ヒトとアカゲザルは hemochorial で同じ分類に入るが，ヒッジは syndesmochorial でかなり異っており，ブタ，ネコあ夫々別に 分類される。アカゲザルとヒトと胎盤の相違は, アカゲザ ルが通常単胎であるのに 2 ケの胎盤を有すととである。 
表 1 新生哺乳動物器官の重量

（出生時体重に対する百分比）

\begin{tabular}{|c|c|c|c|c|c|c|c|c|c|}
\hline & & 脳 & 肝 & 骨格筋 & 骨 & 皮膚 & 心 & 肺 & 報告者（年） \\
\hline \multicolumn{2}{|r|}{ 人 } & $10 \sim 13$ & $3.5 \sim 4.3$ & 18 & 14 & - & $0.5 \sim 0.65$ & $1.5 \sim 1.8$ & Gruenwald(1960) \\
\hline \multicolumn{2}{|r|}{ 豚 } & 3. 7 & 4. 7 & 30 & 24 & 10.5 & 1.0 & 2.2 & McMeekan(1940) \\
\hline 緬 & 羊! & 1. 3 & 2.1 & 22 & 23 & 11 & 1. 0 & 1.8 & Carlyle (1948) \\
\hline \multicolumn{2}{|c|}{ 犬 } & 3.3 & 9.6 & - & - & - & 1.5 & $\overline{2.7}$ & Hosein \\
\hline \multicolumn{2}{|c|}{ |猿(Rhesus) } & 12.0 & $\underline{3.3}$ & 25 & - & 12.6 & 0.6 & 1. 0 & Shelley, Dawes \\
\hline \multicolumn{2}{|c|}{ 猫 } & 3.3 & 4. 1 & 30 & 12 & - & 0.9 & 2.5 & Altman(1962) \\
\hline 家 & 兔 & 2.9 & $6 \cdot 6$ & 15 & - & 19 & - & 2.6 & Dawkins (1964) \\
\hline モ & ルモット & - & 4. 8 & $14 \sim 16$ & - & 16 & 0.5 & 1.5 & Altman(1962) \\
\hline ラ & ッ & 5 & 6.3 & 15 & - & 15 & 0.5 & - & $\operatorname{Altman}(1962)$ \\
\hline$\checkmark$ & ウ & 6.3 & 4.3 & - & - & - & 0.5 & 1. 4 & $\operatorname{Altman}(1962)$ \\
\hline
\end{tabular}

表 2 胎盤の組 織 学的分類

(Grosser, 1909)

\begin{tabular}{|c|c|c|c|c|c|c|c|}
\hline \multirow{2}{*}{ 組 織 分 類 } & \multicolumn{3}{|c|}{ 母 体 側 } & \multicolumn{3}{|c|}{ 胎 巟 側 } & \multirow{2}{*}{ 動 } \\
\hline & 内皮細胞 & 結合織 & 上皮細胞 & 栄養細胞 & 結合織 & 内皮細胞 & \\
\hline Epitheliochorial & + & + & + & + & + & + & 豚 \\
\hline Syndesmochorial & + & + & - & + & + & + & 羊, 山羊, 牛 \\
\hline Endotheliochorial & + & - & - & + & + & + & 猫, 犬 \\
\hline Hemochorial & - & - & - & + & + & + & 人，猿 (Rhesus) \\
\hline Hemoendothelial & - & - & - & - & \pm & + & $\begin{array}{l}\text { 家克, モルモット, } \\
\text { ラット, マウス }\end{array}$ \\
\hline
\end{tabular}

表 3 胎盤における酸素移動

(Metcalfe, 1967)

\begin{tabular}{|c|c|c|c|c|c|c|c|c|c|}
\hline & & $\begin{array}{l}\text { 胎 } 1 \\
\text { 満期 }\end{array}$ & $\begin{array}{l}\text { 児重 } \\
(\mathrm{kg})\end{array}$ & $\begin{array}{l}\text { 子宮血流量 } \\
\left(\begin{array}{l}\mathrm{m} \ell / \mathrm{kg} \cdot \mathrm{f} \\
/ \mathrm{min}\end{array}\right)\end{array}$ & $\begin{array}{l}\text { 子宮 内 } \\
\text { 酸 素消 費 } \\
\left(\begin{array}{l}\mathrm{m} \ell / \mathrm{kg} \cdot \mathrm{f} \\
/ \mathrm{min}\end{array}\right)\end{array}$ & $\begin{array}{c}\text { 酸素消費率 } \\
(\%) \\
\text { (\%) }\end{array}$ & $\begin{array}{c}\text { 子宮血流比 } \\
(\%)\end{array}$ & $\begin{array}{c}\text { 母-胎 } \\
\text { 酸素分圧差 } \\
(\mathrm{mmHg})\end{array}$ & $\begin{array}{c}\text { 胎盤拡敗能 } \\
\left(\begin{array}{l}\mathrm{m} \ell / \mathrm{kg} \cdot \mathrm{f} / \\
\mathrm{min} / \mathrm{mmHg}\end{array}\right)\end{array}$ \\
\hline \multicolumn{2}{|c|}{ 人 } & & 3.3 & 150 & 7. 4 & 30 & 10 & 23 & 0.32 \\
\hline \multicolumn{2}{|c|}{ M. mulatta } & & 0.4 & $\underline{145}$ & 10.0 & 50 & 5 & 33 & 0.30 \\
\hline 緬 & 羊 & & 3.0 & 330 & 9.0 & 30 & 20 & 40 & 0.20 \\
\hline 山 & 羊 & & 3.0 & 325 & 12.0 & 28 & 20 & 40 & 0.30 \\
\hline 家 & 鬼 & & & 83 & 7. 7 & 71 & & 10 & 0.70 \\
\hline
\end{tabular}

子宮血流量については，ヒトの満期では $124-150 \mathrm{~m} \ell / \mathrm{kg}$ fetal weight $/ \mathrm{min}$. であり, アカゲザルの妊娠最終月は $146 \mathrm{~m} \ell / \mathrm{kg}$ fetal weight $/ \mathrm{min}$. でよく似ているが, ヒ ッジはヒトより大きな血流量を示している。胎盤におけ る酸素移動をみると(表 3 ), 胎盤に抢ける酸素の拡散能 力(diffusion capacity) は, ヒト, アカゲザル, ヤギで よく類似しているが，ヒッジは，やや小さい值を示す。
胎仔の循環に関する系統的な研究は, ヒッジの胎仔, 新 生仔を用いての Dawes らの業績がある。最近 Behrman らは, アカゲザルを用い, RI t tracer として, 重要 臟器の血流量を調べた。その結果は分時拍出量に対する 各臟器への血流量は脳が多く, また胎児仮死の場合に増 加するといっている。このことは, 脳を, 種々な障害か ら保護しようとする生体の防禦反応として考えられ, 興 
表 4 周産期中枢神経障害とサル実験（Rhesus monkey）

1. 中枢神経の構築の人間との類似性

2. 交尾日のはっきりした妊娠サルの入手と維持が適当な值段で可能。

3. アカゲザルは利用し易く，それ程高価でない。

4. アカゲザルの生殖繁殖はいろいろな点で人間と類似。

5. 出生時の体重（400-500 GM)，大きさが実験手技に適している。

(Ronald E. Myers)

味樑い。出生時の新生哺乳動物の血圧についてみると, ヒト $53 \mathrm{mmHg}$, ヒッジ $65 \mathrm{mmHg}$, アカゲザル $45 \mathrm{~mm}$ $\mathrm{Hg}$ で近似しているが，他の小動物では低い。酸素消費 量については，ヒトを含め, 動物によって異なり, 類似 性を求めがたいが，環境を徐々に変化させた場合の反応 の patternはヒトとサルでよく類似しているようである。

胎生期から新生児期にかけての代謝面の変化について は，肝に打ける glucose-6-phosphatase の動きをみる と，ヒトとアカゲザルで比較的類似しているようであ る。肝の glycogen の動きもヒトとアカゲザルとの間に 類似性があるが，アミノ酸については，ヒトを含め動物 により差異がある。

以上を綜括すると, 循環の面ではヒトとサル（アカゲ ザル）とは比較的よく類似しているようであるが，酸 素消費量, アミノ酸代謝等, 代謝面では, 動物によりか なり相違があり, この辺にモデルとしての, 有効性と限 界がある。

出生時の仮死亡, 予後については, アカゲザルを用い ての Windle らの研究がある。アカゲザル新生仔を仮死 状態にし, その後䚢生し, 短期, 長期の観察を運動, 学 習面より行ない, 一見正常にみえるサルでも, 仮死にな ったサルは, 病理学的検索で, 脳に何らかの異常がある といわれている。

胎児, 新生児学研究のモデルとして, サルを用いる場 合, 殊飞子宮内環境亡胎児の関係を研究する場合, 胎児 に対し, 子宮内手術操作を行ない, 胎児血管に catheter を挿入し，長期に胎児の状態を生理的または代謝面から 観察する，いわゆる chronic experiment（慢性実験） をしなければならない。子宮内挿作あるいは採血量から 屯, ある程度の大きさを必要とする。これまで欧米諸国 であ, これから研究のため, カニクイザル, アカゲザ ル，ヒヒなどが用いられているが, 胎児, 新生児生理学 実験には主にアカゲザルが用いられていることは，大き さ，扱い易さ，入手し易さなどの点を考慮し，その最大 公約数としてアカゲザルが適当と考えられたあのと思 う。胎児・新生児学は, 今世紀, 殊に最近の 30 年間に発 展したあのであり，その前途は遼遠である。この分野で の研究の発展のためには, サル類がぜひとも必要である ことを，いささかなりともご理解いただけたものと信じ
る。周産期中枢神経障害とサル実験について Myers は 表 4 のごとく述べている。本邦では, 必らずしもてれと 合致しないかむ知れないが，われわれ，胎児新生児学を 学ぶあのにとって, 少しであサル類をモデルとして研究 に用いることができることを念願して止まない。

講演の機会を与えて下さいました。会長および座長に 感謝いたします。

\section{主な参考文献}

1) Behrman, R. E., Lees, M. H., Peterson, E. N., deLannoy, C. W., \& Seeds, A. E. Distribution of the circulation in the normal and asphyxiated fetal primate. Am. J. Obstet. \& Gynec. 108 : 956-969, 1970

2) Dawes, G. S. Fetal and neonatal physiology, Year Book Medical Publishers, Chicago, 1968

3) Fetal and Neonatal Physiology: Proceedings of the Sir Joseph Barcroft Centenary Symposium. Edited by Comline, K. S., Cross, K. W.' Dawes, G. S. \& Nathanielsz, P. W. Cambridge University Press, London, 1973

4) Physiology of the Perinatal Period. Edited by Stave, U., Appleton-Cehtury-Crofts, New York, 1970

5) Windle, W. F. Physiology of the Fetus. Charles C Thomas Publisher, Illinois, 1971

6）鈴木康太郎, 胎児生理学の展望 医学のあゆみ, $82 ; 1012-1019,1972$

\section{6. 栄養と発育}

畠山富 而（岩手医大·医）

近年, 栄養と脳発達, とくに低栄養との関係が乳幼児 期を中心に大きな課題になっている。ネズミ，豚などの 実験的研究において, 妊娠中の母体の低栄養と胎仔の関 係, さらに出生後の幼若時期の低栄養との関連など, 脳 発達に执よぼす影響が Winick, Dobbing らにより系 統的にエネルギッシュに追求され，とくに脳のDNA 含 量, RNA 含量, 脂質含量について詳細な報告が行われ ている。われわれ屯低栄養，とくに低蛋白栄養が生後間 
あない乳児期に生じた場合，脳発達におよぼす影響を検 討するためヒトに近いサル（カニクイザル）を実験動物 として研究を行っている。ての研究は，その緒についた ばかりでシンポジゥウの表題に対して適切な意見になる かどうか不充分ではあるが，研究経過を述へ，その中か ら推察できる “ヒトのモデルとしての有効性について” 一部の研究と共に報告する。

I 人工調製乳による飼育実験：幼若時期の低栄養に よる仔ザルの飼育実験を行うため, 前段階として人工調 製乳による飼育実験を行った。実験方法は生後 1 週間前 後の仔ザルを母親ザルより離し, 人間の未熟用保育器に $25 \mathrm{~cm} \times 30 \mathrm{~cm} \times 30 \mathrm{~cm}$ のージを入れ，その中収容した。 ケージの中には布で被った枕様のあのを常時㨂入してお いた。哺乳は動物用の哺乳ビンを使用, 人工調製乳は市 販育児用ミルク $\mathrm{P}_{7 a}$ を $12 \%$ 亿して哺乳した。室温 $25^{\circ} \mathrm{C}$, 湿度 $65 \%$ とした。授乳方法は手に抱いて哺乳させた群と 哺乳ビンをケージに差し込んでおいた群とに分け，授乳 回数は 1 力月令まで 1 日 6 回, 2 力月令まで 5 回, 3 力月 令まで 4 回とし，その後は離乳食を与え，授乳を漸減し た。飼育結果：身体発育は野生妊娠と国立予研妊娠そし て国立予研出産に分けて観察したが，国立予研妊娠出産， 母乳育成サルと比較すると人工調製乳住るる飼育例は発 育は上回る傾向を示した。とくに国立予研妊娠出産群が 良好の発育を示した。生後 $3 \sim 6$ 週の 1 日体重増加量は $7 \sim 8 \mathrm{~g}, 7 \sim 10$ 週頃 $6 \mathrm{~g}, 10 \sim 11$ 週頃江生下時体重の 2 倍 になった。栄養摄取状況は人工調製乳の哺乳量から逆算 したため仔ザルにとって適切であるかどうか論議のある ところであるが $3 \sim 6$ 週, カロリ $-240 \sim 260 / \mathrm{kg} /$ 日, 蛋 白質, $6 \sim 7 \mathrm{~g} / \mathrm{kg} /$ 日, 水分, $400 \sim 420 \mathrm{~m} \ell / \mathrm{kg} /$ 日, $7 \sim 8$ 週に扔いてあ殆んど同じで離乳期，カロリー 200〜240/ $\mathrm{kg} /$ 日, 蛋白量 $5 \sim 6 \mathrm{~g} / \mathrm{kg} /$ 日, 水分, $400 / \mathrm{m} \ell / \mathrm{kg} /$ 日 で あった。

II 低栄養飼育実験：人工飼育が可能となったため， 所期の目的の低栄養飼育実験を行った。乙の研究は仔ザ ルの損失が多く困難であるが， 2 頭の低栄養飼育例と 1 頭の重度低栄養飼育例に成功した。乙れは人工調製乳の うち蛋白量を $1 / 2$ 含量とし，その分のカロリーを糖質で補 った人工乳を作って哺乳させたあのであり，前者は $12 \%$ の人工調製 1 日 4 回の哺乳之低蛋白人工乳を，後者は低 蛋白人工乳を与えて飼育したもので前者は対照の体重に 対して $4 / 5$, 後者は $3 / 5$ の体重発育を示した。

II 低栄養と脳発達, とく江脳 DNA と脳脂質につい $て:$ 上記飼育実験を行った人工栄養群, 重度低栄養と各 々の対照として母乳栄養群との間に比較を行った。低栄 養群の 1 例において, 頭頂部, 後頭部, 小脳の DNAは やや低值を示したが, 重度低栄養の仔ザルの頭頂部, 後 頭部，小脳においては DNAは著明な低值を示した。ま
た脂質の中からフォスフォグリセライドを例にとると重 度低栄養に㨟いて，ミエリン鞘形成に関与すると思われ る脂肪酸が著明な減少を示しており，とくに白質に強い 傾向を認めた。

VI 人工飼育と行動異常：玩在, “Isolation Monkey" “Monkey Psychiatry”など話題になっているが，われ われの飼育実験は未熟児用保育器でしかも人工乳による ため，母親ザルに育てられた仔ザルには見られない行動 異常が観察された。すなわち, “autistic-like self-mouthing", "self-clasping", "huddling”, "stereotype rocking” “head-knocking”, “aggressive behaviour”などであり, しかむ哺乳条件の差により行動異常にも差のあるととを 確認した。

以上の実験結果から推論するととが許されるならば， 小児科医の立場として妊娠時母体栄養すなわち胎児栄養 之胎児発育, さら汇出生後の早期幼若時栄養が, それぞ れの時期において, 如何なる影響を身体発育に与えてい るのか, とくに脳発達におよぼす影響について, 脳細 胞, DNA 含量, RNA 含量, また脂質その中でも燐-, 糖脂質の動向，ミエリン鞘形成との関連など，中枢神経 系の発達についてはな打詳細は不明であるが，燐脂質な どはヒトの燐脂質に極めて類似の状態を示しており, サ ルによる実験は組織学的研究と共傮極めて重要な示唆を 与えてくれるあのと予測される。同時に母乳栄養と人工 栄養の際の発育パターンの差異, とくに骨発達, 骨組 成, 歯の組成など, サルと人の乳汁の内容が極めて近い ことと相まって市販ミルクの検討にもおよばなけ机ばな らない。また, われわれの実験において観察された Isolation Monkey としての行動異常はヒトの乳児に見 られる「クセ」と非常に似ている行動が多く, 比較動物 学的に行動の意義についても, より慎重に追求されなけ ればならない。さらに哺乳時の条件の差により行動, 行 動異常にも差が認められたととは, 母子関係の原初的意 義の解明, さらに最近, 大きな課題となっている自閉 症などを含めた情緒障害の問題住対しても“Monkey Psychiatry”を通じてつの方向が導き出されるのではな いかと期待したい。われわれは乳幼児のモデルとして仔 ザルを使用しているが，その限界については研究目的に よっては予知されるあのも多くあると思われるが，目下 この実験研究のレベルでは答を出すほどに至っていな い。

上述の諸実験は国立予研獣疫部実験動物第 2 室との共 同研究の一部である。

\section{7. 神経生理の立場から}

$$
\text { 真 野 範 一（都立神経科学総合研） }
$$


はじめに： 神経生理学の分野に扔いて, サルを実験 動物として用いた研究が近年急速に増えてきている。ま た, 現在はネコ等を用いている研究者達の中にも, 条件 が許されるならサルを使って研究をやりたいと考えてい る者が増えてきている。本日は第一に, なぜサルを用い ての研究が神経生理学の分野で増えつつあるが?”之い う研究史的展望, 第二に“わが国においてはサルを使い たいという研究者の希望がきわめて不充分にしか満たさ れていない実状にあるのはなぜか?”について述べる。 研究史的展望：中怄神経系の生理学の歴史を顧みると 1950年頃を境として大きな進歩があった。それ以前の研 究は中枢神経系を black box として扱うか, 非常に多く の神経細胞群を十把一からげにして研究を行なってい た。例えば，1870年に Fritsch and Hitzig が大脳皮質 を電気刺激するととによって運動領の局在を発見した が，たしかに大脳全体からみると，限局した部位を電気 刺激しているが, 神経細胞レベルで考えると, 非常に多 くの，おそらく数十万個の細胞を同時に刺激していた。 今世紀初頭に活躍した Sheringtonの脊䯣反射学にして あ, また Pavlov の条件反射学にしても, 中枢神経系に は手をつけずに筋肉の動きや唾液の量を indicator とし て，神経系の働らきを間接的に推論していた。その後, エレクトロニクスの発達, 特にブラウン管オッシロスコ 一プの生理学への導入があってから次第に実験の精度が 高まり，1952年には J.C. Eccles 等により“細胞内記録 法の中枢神経系への導入”が成功し, 細胞レベルでの研 究が急速に進歩した。その成果の一端を紹介すると, 神 経細胞はその機能に二種類（興奮性と抑制性）があり， この二種の神経細胞が様々な結合様式で複雑な回路網を 構成しているのが中枢神経系であり，1950年代1960年代 には次々とその回路網が解析されて目覚しい進歩があ り，わが国の神経生理学者も非常に大きな貢献をした。 その結果, 今世紀前半には black box であった中种神 経系の多くの部分が神経細胞レベルで明確に理解できる ようになってきた。しかし, 研究の発展ととあに, 細胞 内記録法の技術的，理論的限界が明らかとなってきた。 すなわち，脊髄反射のような簡単な現象は，神経回路網 がわかると，それですっきりと説明できるのであるが， あう少し複雑な現象になると回路網の解明だけでは充分 理解できないととが明らかとなり，新しい研究方法論が 必要とされるようになった。その一つとして “無麻酔動 物で正常に機能しつつある神経回路の個々の神経細胞活 動を観察すること”が近年有力な方法として注目されつ つある。ただ単に無麻酔動物から単一神経細胞活動を記 録することはすでに1957年に H. JasperらやD. H. Hubel らによって工夫され感覚生理学の方面で応用されていた が，1966年に E. V. Evarts が更にひと工夫加えてから
この方法が急に注目されるようになった。そのひと工夫 とは, 近年進歩した論理演算回路を応用して, サルに一 定の動作をオペラント条件づけし，乙の動作をサルが自 発的に行なっている時に神経細胞活動を記録するのであ る。この方法によよば動物の自発的な動作の反復性ない しは再現性が得られ神経活動との因果関係を客観的に分 析するととが可能となった。例えば反応時間法という最 あ簡単な動作を訓練するととによって，大脳皮質運動， 大脳基底核，視床，小脳皮質，小脳核などで随意運動の 開始前 $50 \sim 100$ ミリ秒に神経細胞活動の変化が観察され た。すなわち，てれらの部位が随意運動の開始に何らか の役割をはたしていることが実証されたわけである。反 応時間法の他にも遅延反応, 追跡作業, 交互ボタン押し などの動作が訓練可能であり, 中枢神経系の研究に非常 に有効なととが実証されつつある。

このような研究方法の変化は同時に実験動物の変化を 伴なっている。細胞内記録法のような急性実験では主と してネコが用いられ，Evarts の方法のような慢性実験 にはサルが主として用いられる。前者の場合, 脊髄の手 術がやりやすいという他に，一つの論文を書くには40〜 50匹の実験動物を必要とするため，高価なサルは研究費 の面から使用できないのが大きな理由である。後者の場 合, それ程数多くの動物を使用せずとも一つの研究がで きる他に, 訓練の容易さ, 形態, 機能のヒトへの近縁と いう理由がサルを実験動物として選ばせろ理由となって いる。

日本の神経生理学会での実状：以上述べたように実験 動物としてのサルの有効性が認識されてから日が浅く, その限界を論ずる時期には達していない。むしろ，サル の有用性が認識されればされる程, 実際にサルを用いる ことの困難な現状が痛感される。その理由の第一は検疫 体制の不備，第二は研究費の貧困である。現在の日本で は使用する各研究機関において検疫を行わざるを得ない 実状であり，乙れをWHO の勧告通り飞行える機関は 非常に少なく，神経生理学者が利用できる唯一の機関之 して京大の霊長研があるのみである。したがって検疫体 制の整備されていない研究機関では，輸入された無検疫 のサルを危険をおかして使用するか，ある程度検疫のす んだ非常に高価なサルを用いざるを得ない。現在の日本 の科学研究費の実状からして, 年間に数十頭以上を必要 とするような実験は不可能に近いわけである。

以上のようなわが国の現状では, 神経生理学の分野で サルを用いることのできる研究者は非常に限定され，乙 の方面での研究の立ちおくれを心配せねばならない。か 汃る現状を抜本的に解決するには, 国のレベルで実験動 物としてのサルのサプライセンターを設立し, 政府の強 力な経済援助が行なわれる必要がある。 


\section{8. 心理 ·行動}

糸魚川 直 祐 (阪大人間科学部心理学研究室)

(1)問題点本来は人間を研究対象にする心理学が，な ぜ動物実験を行なうのか。サルを取り上げるまえに，動 物実験が心理学のなかでどのような位置を占めているか を考えてみたい。

心理学の研究方法に実験が採用され, 近代心理学がう ち立てられたのは，今世紀の初めであるが，動物実験は 近代心理学の出発に少なからず貢献した。近代心理学は それまでの主観的心理学を批判し, 心理学の研究対象は われわれが実験によって客観的に調べるととのできる行 動であるとした。てのような考え方に立って心理学を発 展させたのが，アメリカにおける行動主義心理学者であ り，かれらは動物実験を重視した。行動主義心理学が動 物実験を重視したのは, 他の生物諸科学に共通の理由に よるばかりではなく，心理学に固有な理由汇もよると思 われる。心理学は行動を研究するが, 行動とは体の部分 的な反応や運動ではなく，人間や動物の全体的な適応の いとなみである。てのような全体的ないとなみをみる と, 動物を人間の代用にして行動を研究するには, 両者 のへだたりは大き過ぎるといわざるをえない。行動主義 心理学が動物実験を重視したのは, 動物が人間の代用に なるとみたからではなく，動物実験が行動つ客観的な研 究方法を探究するのに役立つと考えたからである。研究 者である人間は，動物の主観的な心を読み取ることはむ つかしく, 動物も心の状態を言語活動などで直接表出す るととはできない。したがって，動物にたいしては最す 客観的な方法で行動を研究することが要求される。行動 主義心理学はこのような客観的な研究方法が人間にも適 用されるべきであると考えた。

行動主義心理学などによる動物実験の結果, いくつ屯 の重要な研究方法が開発された。しかし，もともと動物 実験は人間と動物とを直接比較する目的を持たなかった ため, 動物実験によって開発された研究方法は，一旦人 間研究の分野汇適用されると独自の発展をとげ, 同じ方 法によって人間と動物とを比較したり，動物を人間のモ デルに用いようとする試みはほとんどなされなかった。 動物実験が人間との比較のためではなく, 研究方法の開 発や, 行動理論の構筑のためであったととは, 実験に用 いられた動物が人間との近縁性よりも, 実験統制や飼育 の容易さによって選ばれていた事実からも明らかであ る。

ところが，サルなど霊長類の研究は，乙れまでの動物 実験とはちがい，お屯に人間と比較する目的のために誕 生した。乙れは霊長類が多くの点で人間似ているから に他ならない。とくに, かれらが個体発達のうえで, 社
会的な経験を通じて適応のしかたを学んでいく過程は， 人間の場合と対比されるべきものである。次に，てのよ うな個体発達汇関する実験を例に, 霊長類研究の有効性 について述べる。

(2)有効性述年, 人間幼児の初期行動発達に関する研 究が注目されている。生後半年頃までの幼児を用い, 視 覚図形を弁別させる実験, 音刺激とミルクにたいする反 応を条件づける実験, ほほえみの表情の現れかたを調べ る実験などの結果を検討すると, かれらの刺激弁別能 力, 学習能力, 対人反応などは, 一般に考えられている よりあ早く発達するらしい。したがって, 発達の初期に おける幼児の生育環境は, われわれが推測するよりああ っと重大な影響を幼児の成長に及ぼし，不適正な生育環 境は，幼児にさまざまな障害を与えていると思われる。

不適正な初期生育環境による幼児の行動異常や精神障 害は, 小児精神医学や臨床心理学によって指摘されてい るが，乙の問題を人間を用いて実験的に解明するととは できない。われわれの研究室では, 約10年間にわたり野 外と実験室でニホンザル幼体の行動発達を研究してい る。とくに実験室では, 生後 1 年末満のさまざまな時期 に子ザルを母から離して単独で育て, 社会的な生育環境 の変化が子ザルの行動発達にどのような影響を及ぼすか を調べている。隔離飼育された子ザルは，野外にいるも のや実験室で母と一緒に飼育されたものにはみられない 特異な行動を示すようになる。例えば，自分の手足の指 やペニスをなめる,体を握りしめる,頭を傾ける姿勢をと る，じっっとうずくまる，頭を床に押しつける，ジャン プをくり返す，檻の中を動きまわるなどの行動である。 子ザルがこのような行動をし始めるとなかなか止めず， 成長しても常習的汇行なうととが多い。乙の行動は一般 に常同行動（stereotyped behavior）とよばれ，人間の ある種の精神障害者の示す行動保外見上類似している。 常同行動の特徽は，外界や他者にまではなく自分の体に かかわる点で自閉的であり, 同じ行動がくり返される点 で類型的であり, 長期間続けられる点で固着的である。 どのような型の常同行動が隔離後いつ現れるかは, 隔離 されたときの子ザルの発達段階によってととなる。ま た，子ザルの性や母ザルの行動特性が関係しているよう である。

隔離飼育によって現れるサルの常同行動と, 人間の精 神障害者の示す行動が外見上似ており，また，行動の自 閉的, 類型的, 固着的な特徵が共通するととを考える と, 初期生育環境を操作し行動異常の原因を解明する実 験に霊長類を用いるととは，有効な方法と言えよう。 (3)限界霊長類は人間を直接実験できない場合の代用 になるため，他の動物よりも実験動物として優れている 点が多いが，霊長類がどてまで人間の代わりになるかは 
問題である。行動発達の研究についても, 生後間もない 期間での霊長類と人間との行動の比較は, 成長した後で の比較と同じではない。両者の比較は, 個体発達の全過 程を通じて，なされなければならない。したがって，初 期生育環境の変化によって生ずる行動を手がかりに，人 間行動研究のモデルを霊長類に求めても，断片的なモデ ルにならざるをえない。

こう考えると，たとえ霊長類を用いても，人間と直接 比較できるモデルを動物実験に求めるのは限界がある。 したがって，心理学における動物実験のねらいに，それ ぞれの動物の種の特性に応じた研究方法を探究し，それ によって種に固有な適応のしかたを明らかにすることで ある。そのうえではじめて人間と動物との比較が可能に なる。

霊長類はさまざまな点で人間化似ているが，表面的な 類似点で両者を比較したり，代用させたりすることは誤 りである。一言に霊長類といっても，さまざまな種を含 んでおり，それら全体の適応のいとなみを明らかにした うえで，人間と比較すべきである。

\section{第 2 部 自然保護, 飼育・生産管理の立場か ら}

\section{1. 野生ザルの保護と利用}

水原 洋 (城日本モンキーセンター)

野生のサル類の保護と利用については，従来何度とな く議論が行なわれて来た筈であるが, 霊長類の研究遂行 上，避けて通ることのできぬこの対語の意味内容や概念 規定を明確にするための議論は，必ずしあ効果的に行な われたとはいえない。また，実験動物学の研究上の必要 から保護と利用を論じる場合，乙の二つの用語について の理解にある種のかたよりがあったととは否めないし， とくにフィールド・ワーカーとラボラトリー・ワーカー との間に相互の誤解が生じがちであったととあ事実であ る。しかしながら, 実験動物学が, 霊長類の生物学的研 究の一役を担う基礎学であり，また霊長類学の一分野で ある以上，この二つの用語に関して他の分野例えば生態 学との間に互いに本質的に異る見解を生じる余地は本来 ない筈である。すなわち，保護とは，サル類の自然の生 活の保護のことであり, 利用とは, 保護を前提とした学 問的利用でなくてはならないのである。

次に，研究者は第一義的には常に自然の利用者である ことを忘れてはならない。そうして研究者にとっての自 然 〜この場合はサルの自然の生活であるが〜の保護と は, 利用し得るナチュラル・リソースの保存を意味する。 こうした立場に立つ以上, 保護が, 学問の直接の目的
ではなく，利用のための必要な手段であることは改めて いうまでもないが，ただ，その保護は，接近の動機が極 限されているとはいえ，保護その屯のを目的とした自然 環境ぐるみの動物の保護と同じトータルな保護にあ通じ るものであある。その理由は, 実験動物学が霊長類学の 一分野であって，他の諸分野における研究と等しく，サ ルとは何か，という共通の課題を，その学問研究の目的 として分有しているからに他ならない。今，サルとは何 か，という問いかけを，二ホンザルとは何か，と具体的 にいいかえてみよう。ニホンザルとは何か，という問い は，二ホンザルという種の進化系統上の位置を明らかに する，という仕事を結果として期待している問いである 加ら, 利用のための保護といっても，その保護は，二木 ンザルを “種”として保存するととを意味する。そうし て種としての保護は, 当然のととながら，二ホンザル が，日本列島の自然条件汇適応して来た歴史的過程を考 えに入れての，かれらの生息環境ぐるみの保護でなけれ ば意味がない。したがってニホンザルの保護は, 従来と あすれば狭義にとらえられて来た，“研究用に消費が見 てまれる需要量によって決定される，ある生体量の，涸 渴のおそれなき確保”にとどまらず，それを超えた，

“種としての保存”を，今後とあに目指さざるを得なく なるであ万う。ここに，“利用を前提とした保護”とい

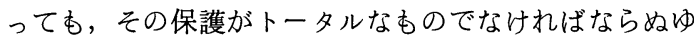
えんがあるのである。

以上述べたととは, いわば自明の理ともいえることで あるが，実際の研究活動の上では明確に認識されたとと がなかったてともまた事実である。例えば，かつて，日 本モンキーセンタ一等が中心となって設立した，全国の 野猿公苑管理者の協議体であった日本野猿愛護連盟の規 約には, “学術研究に寄与する”という一つの目的を達 成するための事業項目として “実験用サル供給に対する 協力”をあげていた。同連盟発足当時, てのような “事 業”が規定されていたという事実は，一部の有力な生態 学研究者之実験動物学研究者之の間に, 野猿公苑を, サル の “生産場”之見る, 利用者どうしのなれ合いがあった ということを示している。またてのととは同じ事業内容 の中に，“野猿の適切な保護繁殖”なる一項が併記され ているのを見ても明らかである。すなわち飰づけされた サルたちの保護乃至愛護は, はじめから“繁殖”とセッ トにされていたのである。保護と繁殖とは, 当然のこと ながらちがう。とくにニホンザルの種としての保存とい う見地から見れば，“繁殖”は，往々にして保護の姿勢 之矛盾する性質のあのである。その意味で，“愛護”連 盟の一部の創始者たちは, 野猿公苑の餌づけされたサル たちを, 自然からの直接の収奪に次ぐ, 第二次の収奪の 場と考え，野猿公苑のサルたちが，そのためにかれらの 
自然の生活の場を失なったり生活型を維持できなくなる ことには考慮を払わなかったといえる。その結果，各地 の野猿公苑は荒廃を続け，本来の保護の精神に反する悪 しき管理体制をはびこらせる結果を招いたのである。

保護と繁殖とを安易に混同し，資本金を配当に迴すの 愚をおかさぬためには，繁殖用のコロニーを，野外，準 野外施設, 屋内施設の各段階にわたって設置し，機能せ しめる以外にはない。乙れによるコストの上昇や使用上 の制限は利用者にいくばくかの不自由を強いるかす知れ ないが，それはまた別の次元での解決策が見出されるべ き問題であろう。自然からの無差別な収奪や，真の意味 で実験動物といえない動物を平気で利用するようなとと が依然としてまかり通っていたのでは，実験動物学の今 後の進歩は望めない。との方がはるかに大きな問題とい わねばなるまい。

\section{2. “ノーマルデータ”および “自然発生の疾病”}

和秀 雄 (日本モンキーセンター)

I “ノーマルデータ”について

小はマーモセット類から大はゴリラにいたる，約 300 種に及ぶサル類の，しかも，血液生理，生殖生理などと いった極めて広範囲の各種の生理值について，限られた 短加い時間内にまとめることは不可能に近い。

したがって，“アカゲザルの血液性状”というような 具体的な数值をいろいろとならべることはやめにして, まずはじめに “生理値”に関する数多くの報告に含まれ る問題点を，の例をあげながら指摘し，野生のサルが使 われることの多いサル類での “ノーマルデータ”の意義 について考えてみたい。

まず問題になるのは “ノーマル”の意味である。例え ば，野生と飼育下のサルを比較すると，野生のサルの方 が健康そうで生き生きとしているが，野生のサルは，寄 生虫感染その他の問題があるし，また血液性 状などで あ, バラッキが非常に大きい。一方, 寄生虫freeなど, 一定のコントロールをうけ，一定の環境で飼育されたサ ルでは, 各種の生理值のバラッキが少なくなることが知 られている。とのどちらを “健康”之考え “ノーマル” とするのか，乙のへんが “ノーマルデータ”という場 合，まず問題になるであろう。

また，地域差や棲息環境の差，年齢や性による差，と いうような各種の条件による差も問題になる。

例えば，サル類の “生理值” に関する数值が，報告者 によって差があるのをしばしば経験するが，方法やテク ニックによって生じる差も考慮されねばならないとして あ，環境などの条件のちがいが大きく影響するであろう ことは当然予想できる。事実, 演者らは, 各地のニホン ザルの血液検査を行ない，群れによって若干の差がある

\section{ことを確認している。}

したがって，かりに“アカゲザルの云々”といった報 告があるてあ，それは決して全アカゲザルを代表し得る あのではなく，“ある報告者の”“ある地方の”あるい は “ある条件の”といった前置詞をおいて読みとること が必要である。

さらに, 最む問題になるのは, サルの個体性の問題で ある。

一般にサル類の実験では，一つの実験に何十頭もグル 一プで使うことはまれで，“個として扱う動物”の部類 に入る。しかも，その“個”は夫々“個性”をむち， “生理值”にはバラッキが大きいため，系統が確立され， 温・湿度, 飼料などの環境や, 病気のコントロールがな されている，マウスなど，グループとして扱う実験動物 とはちがった考え方をしなければならない。ちょうど， ヒトの臨床医学が，“ノーマルデータ”を参考にしなが らあ，最終的には各個人の問題にしていくのと同じよう に，サル類の場合あ，各種の報告の数値は，大まかな参 考にすることはできるが，より信頼性のある数值は，各 研究者が，夫々の所で，各個のサルを対象にしながら， 自からつくっていかざるを得ないというのが現況であろ う。

次に，サル類は “ヒトに最す近い動物”として，その 特性が十分に吟味されないまま珍重される傾向も出てき ているが, 呼吸数, 体温はむち万ん, 血液性状や生殖生 理の面であヒトとはちがう面ああって，安易に“上卜の モデル”とみなすととはできない。サル類の特性をよく 心得た実験計画を組まないと，思わ障害にぶつかった り，良い成績が得られないととも多い。

また，野生のサル類の保護という観点加らっって， サル類の生理や特性をよく知り, 必要なものだけを大事 に使うという立場が必要であろう。

II 自然発生の疾病について

この問題も, 各種のサル類の数多い疾病について詳述

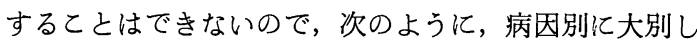
て，夫々の 2,3 例をあげる。

環境

温度 \{低温一一感冒, 肺炎, 凍傷, 凍死など 高温一一熱射病など

湿度低湿一ーマーモセットの気管支炎など ケージ $\left\{\begin{array}{l}\text { 構造一ーケガなどの事故 } \\ \text { 個室—運動不足, 神経症的な疾患 } \\ \text { グループーケガ, 感染症の流行 }\end{array}\right.$

栄養 $\{$ ビタミンC不足一一壊血病 ビタミン D不足一クル病

感染症

細菌性——赤莉，結核など 
ウイルス性——Bウイルス，Mウイルスなよ゙ 原虫性——アメーバ赤痢, トキソプラズマ 寄生虫性一一鞭虫, 胃虫, 粪線虫, 腸結節虫, 鉤頭虫, 条虫, フィラリア, 肺ダ ニなど

その他

一般にサル類の疾病は, 赤痢などのように症状のはっ きりしたあのはまれで，死の直前まで異常に気づかない 場合が多い。そういう意味では, 適確な診断技術の確立 が望まれるが，それ以前に，予防にこそ最大の力がそそ がれるべきである。

また, サル類の感染症の多くは人獣共通伝染病であり, しかあどんな未知の病原体をあっているかあ知れないと いうことを, 常に考慮にいれながらサル類に接する態度 が必要である。

\section{3. 野生環境から実験室への順応および温熱性代謝性 反応からみた飼育管理}

$$
\begin{aligned}
& \text { 登 倉 尋 実 (京大·霊長研) } \\
& \text { 大 野 拓 夫 (名大·農) }
\end{aligned}
$$

実験動物保健飼育管理の根幹は, 遺伝統御, ならびに, 個々の生体の健康維推のための環境統御である。近年, サル類が実験用動物 (Experimental Animal) として 多くの利点を発揮するようになってきたとはいえ，今後 あ増大する需要に対して, 研究目的に質的, 量的に合致 した動物，すなわち実験動物 (Experimental Domestic Animal) として供給することは容易ではない。遺伝統 御と環境統御とを総合的に体系化することにより，初め て目的に合致した動物を供給することができる。

生命科学の研究に用いられているサル類の現状を考え る時, 従来, 経験的に実施されていた飼育管理（環境統 御）に科学的根拠を与えるためには, 野生環境加ら実験 室への順応の過程の生理変化を明らかにし, 広範な視野 から把えた生命現象に基づく飼養環境標準を確立しなけ ればならない。との標準による人為統御は，捕獲野生動 物を実験動物化 (Domestication) する不可欠の過程で あある。

現在, 実験用動物として使用されているサルは, アカ ゲザル，カニクイザル，ニホンザルなど約 30 種であるが， その分布, 生活様式も多岐にわたっており, 生活環境, 特に，生息地に打ける気象条件，栄養環境は大幅に異な っている。このような野生環境から, 捕獲, 輸送による 心理的・生理的ストレスを受けたサル類が, 温度・湿度 ・照明・飼料などを人為的に統御した実験室へ搬入され た場合，どのような過程を経て，ストレスによる異常を 回復し，各種生理值が新しい飼育環境のもとで一定にな っていくかは，十分に明らかにされていない。実験動物
の保健飼育管理にとって, 温度・照明などの気象条件の 変化が，サル類の各種生理機能に抢よぼす影響を調べる ことは重要な問題である。また，乙の影響のあらわれ方 は, サルの種により異なると考えられる。例えば, 体温 調節機能からみて, $5{ }^{\circ} \mathrm{C}$ 寒冷暴露に対し, ニホンザル は，主としてふるえにより，産熱量を中性温度域（室温 $\left.25-29^{\circ} \mathrm{C}\right)$ に比較し， 2 倍以上にあげ，直腸温を一定に

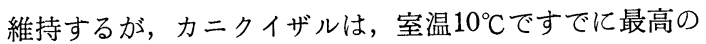
産熱量を示し, $5{ }^{\circ} \mathrm{C}$ の室温では, それ以上に産熱量は上 昇せず，直腸温を一定に保つことはできない。また，0 ${ }^{\circ} \mathrm{C}$ の水水中に片方の手を浸し, 中指末節皮膚温を連続的 に測定し，寒冷血管反応を調べたところ，その反応性は ニホンザル, アカゲザルでよく, タイワンザル, カニク イザルで劣っていた。マントヒヒは, 室温 $40^{\circ} \mathrm{C}$ で産熱量 を著明に減少し，顔面より発汗し温熱平衡を維持した。 ニホンザル，カニクイザルは室温 $40^{\circ} \mathrm{C} に は$ 耐えることは できない。以上のことから, 暑さ寒さに対する許容度 は，種の異なる温熱環境に対する適応能と関係があるて とが考えられ，長期間一定温度環境下で飼育されてい ても, 温熱生理学的特徴は異るととが考えられる。そ こで温熱生理学の立場から野生環境から実験室 環 境へ の順応ないしは飼育環境温度をサルの側から考えると き, それぞれのサルの至適温度, すなわち中性温度域 thermoneutral zone を把握しておくことが，基本的に 重要な問題になってくる。中性温度域は，二ホンザルは $25^{\circ}-29^{\circ} \mathrm{C}$ (Nakayama ら)，リスザルは $25^{\circ}-40^{\circ} \mathrm{C}$ (Stitt とHardy), ピグミーマーモセットは $30^{\circ}-40^{\circ} \mathrm{C}$ (Morrison と Middleton) であると報告されている。中性温度 域を考える場合，野生環境において体温調節反応の季節 差があるのかどうか，季節差があるとすれば，それが実 験室環境でどのようになるのかというととは，野生環境 から実験室への順応の解明のうえで基礎になる。また各 種サル類の生息地の生物相の違いは，食性を多様なもの にし，この食性の違いに対する定量的研究は，サル類の 実験動物化の促進にとって重要な課題の一つである。現 在の飼養状態下において, 実験室環境下において出生し たニホンザルの成長速度は, 野生のものと比較して遅い こと, 成熟ニホンザルにおいて, 給水量の制限は，摄食 量を減少させるとと, そして, 食欲を変動させる要因の 一つとして，サッマイモの給与があげられることなどが 明らかになった。また，二ホンザルおよびアカゲザル成 熟雄の窒素平衡維持時の熟量, タンパク質の所要量を推 定すると，その日量は，二ホンザルにおいて，354 Cal， $2.9 \mathrm{~g} \mathrm{~N}$, アカゲザルにおいて， $314 \mathrm{Cal}, 2.1 \mathrm{~g} \mathrm{~N}$ であっ た。適切な飼養標準を確立するために，飼料中の窒素含 量を日量で3070，1660，954，および3070mgに連続的に 変化させたときの成熟雄ニホンザルの血液性状を給餌直 
前に測定した結果，血液比重は，ほとんど変化しなかっ たが，ヘマトクリット，血漿タンパク質，赤血球，へモ グロビンは, 飼料中の窒素含量の減少とともに減少し, 窒素摄取量 $3070 \mathrm{mg}$ で徐々に増加した。白血球は，窒素 攝取量 $1660 \mathrm{mg}$ で減少し，954mg で徐々に，3070mg “゙ 著しく増加した。窒素摄取量 $1660 \mathrm{mg}$ 以上では, 窒素出 納は正であり，954mgでは負であった。この窒素出納の 変化が, 観察された血液性状に影響する主要な要因であ り, 成熟雄ニホンザルの窒素の所要量は, 日量 954 から $1660 \mathrm{mg}$ の間であると推定される。

以上の結果から, 現在の飼育管理は, 再検討を要し， 適切な飼養環境標準を確立することが，合目的的にサル 類の育成·繁殖·生産の統御を可能にし，サル類の実験 動物としての多様性が付加されるのである。サル類の自 然の生活を守るということが討論されている現在, 飼養 環境標準の確立は, 実験室内での繁殖・育成を志向しな ければならないととは言うまでもない。

\section{4. 生産の必要性と方法}

$$
\text { 長文 昭（国立予研） }
$$

今日, 医学生物学分野において試験研究に用いられて いるサル類のほとんどは野生由来であり, 近代的意味で の実験動物として不適当な，心くつ加の条件を潜在的に 持っている。すなわち(1)各種の病原体を保有している可 能性が大きく，他のサルや，実験結果に悪影響をむたら すばかりでなく，サルに接するヒトにとって危険なすの が多い。(2)年齢・病歴・遺伝形質等が不明のため, 反応 の斉一性を得ることが，むづかしい。(3)サル資源の保護 に無関心なまま，今後むなお，野生サルにだけ依存して 実験を続けるならば，自然界におけるサル資源は，急速 に衰退し，将来，真に必要な実験に使うことができなく なるような事態も予想される。さらに，野生で捕獲され るという，さまざまな不確定要因に支配される流通機構 にも大きな問題がある。これらの不適当な諸条件に左右 されない，質のよい，利用者の要求する規格にあったサ ルは，生産されたものに求める以外に方法はない。

考えられる生産システムとしては，つぎのあのがあ る。

[ I ]屋外方式(1)とくに人工的障壁を作るととなく島，山 など自然の地形を利用して給餌だけをして, 自由に繁殖 するととを期待する方法 (自由放飼生産), (2)八的に 作られた囲いの内で繁殖する方法(制限放飼生産)，〔II] 屋内方式(3檻または, 室内に50頭前後の雌雄を入れて繁 殖する方法 (多群屋内生産)，(4)大型ケージまたは，小 室内で, 雄 1 頭に雌数頭を入れ繁殖する方法（1 群屋内 生産), (5)個別ケージ内で雌雄 1 対 1 で繁殖する方法(個 別ケージ内生産), (6人工授精による生産, 等が挙げら
れる。これらの各生産システムは有機的連関性をもって 運用されることが必要であろう。第 1 のルートとして は，捕獲された野生サルが，まず，I-(1)か-(2)に入れら れ, しかるのち屋内生産システムに導入され，真の実験 動物としての良質なサルの生産がおこなわれる。第 2 に は, 検疫と順化の過程を経たのち, 直ちに屋内生産シス テムに導入するというルートが考えられる。いずれのル 一トをとるかは，施設の規模やサルの使用目的により決 められるであろう。

繁殖群の構成にあたっては，個別ケージ内での個体観 察を入念に行い，とくに雌については性周期の特徴（長 さ, 規則性）を記録する。性周期が短く,規則的に繰返す サルは，個別ケージ内生産に入れのるがよいし，性周期 が不規則なサルは，一群または多群屋内生産システムに 入れるとよい。人工授精による生産は，未だ実験段階を 出ないが, 真にこの生産システムが生かされるためには, 眝蔵精液を用いる方法が開発されねばならない(1)。人工 授精による生産と個別ケージ内生産は，妊娠日令を明確 にできるという利点がある。このように妊娠日令の判っ たサルは, 生産とは別に, 妊娠中のホルモン分泌, 薬物の 毒性, 特に催奇型性, 周産期生理等の試験研究に不可欠 である゚さらに遺伝・育種学的立場からみて, 次の世代の 種ザルは, 父母とも判明している[II]-(4), (5), (6)の 3 シ ステムから生産されたサルに求めるべきである。つぎに 実際の繁殖成績から，いくつかの生産システムの問題点 に触れる。自由放飼生産の例として, 日本モンキーセン ターの野島に扫けるニホンザルの繁殖がある $(2,3,4) 。$ ここでは'69年に65.5\%，'70〜'73年に71.4〜84.4\%の高 い出生率を得ている。この高い出生率は, 生まれた仔ザ ルを, 执よそ 3 力月後に母ザルから分離するという方法 によって得られたあので, 母ザルは, 来たるべき次の繁 殖期にも妊娠 - 出産しうるように仕向けられる。次に, 個別ケージ内生産の例として, 予研の例を挙げる。'62年 に実験として開始してから, '73 年に至る12年間に, 延 179頭の雌カニクイザルから，107頭の妊娠例（妊娠率60 \%) を得た。ここで生産・育成された雌カニクイザル群 の血清蛋白分画値は, 野生由来の繁殖用雌サル群のそれ に比べて $\gamma$-Globulin 值がきわめて低く, Albumin 值が 高く, 同時にばらつきも少さいという，質的に均一な状 態の動物であることが示された(5)。一群屋内生産につい ては，まだ経験も多くはないが，'73 年末までの成績で は，野生雌は52.6\%の妊娠率を示しているが，育成雌は 33. $3 \%$ に過ぎなかった。

ところで，サル類の生産効率をあげるためには, 各シ ステムの有機的連関をむった利用が必要であると同時に サル自身の改良と繁殖育成技術の改良むきわめて必要で ある。サル自身の改良は, 育種, 遺伝学の領域の問題で 
あり，実現にはきわめて長月月を要するであろう。この 例として，カニクイザルにおける妊娠期間の短い動物を 作ることは可能かも知れない。繁殖育成技術面の改良を 考えると，同じく私どもの現在のカニクイザル繁殖コロ 二ーでは, 妊娠·出産・哺育・分婏・回復というサイク ルは, 約 1 年である。すなわち 1 年 1 仔を得る, が出産 と同時に仔ザルを母ザルから分離すると計算上执よそ 2 年間で 3 仔を生産することができる。そして出生直後に 分離した仔ザルの人工哺育技術は，今日既に開発されて いるが，一度に扱う仔ザルの頭数には限界があるので, この限界をどうのり越えるかの検討が為されねばならな い（例えば，条件反射を応用した定時間間隔の人工哺乳 装置の開発)。さらに人工哺育によって，成長したサル の行動については, 行動科学的な観点から, 解決されね ばならない現象が沢山あるととあ忘れてはならない。と くに，どうやって正常な性行動を発現させるかという問 題は重要である。大規模な生産施設においては, 次代の 種ザルは，性行動や育仔行動の正常な発展ということを 期待する場合, 育成のある段階で群飼育システムを導入 する必要があるかあしれない。

生産するサルの種類については, 実験への適性によっ て選択されるであろうが，いずれにしてあ単一の種類で なく複数の種類が必要である。繁殖技術の難易を考慮し サル種を選抜するとすれば，既に，繁殖方式が日常的に 確立し，資料を得易いサル種を採用するのがとりあえず 妥当であろう。

$$
\text { 文献 }
$$

(1) Cho, F. and Honjo, S. (1973): A simplified method for collectng and preserving cynomolgus macaque semen. Japan. J. Med. Sci. Biol., 26, 261-268.

(2) Tanaka, T. and Kotera, S. (1973): Breeding of Japanese monkey on an island as laboratory animal. Procedings of the ICLA Asian Pacific Meeting on Labortory Animals, Sept. 20-25, 1971, Tokyo and Inuyama, Japan., Experimental Animals Vol. 22, 471-478, Supplement.

(3) Nomura, T., Ohsawa, N., Tajima, Y., Tanaka, T., Kotera, S., Ando, A. and Nigi, H. (1972): Reproduction of Japanese monkeys. Symposium on the use of non-human primates for research on problems of human reproduction, Sukhumi, USSR, 13-17 Dec. 1971. 473-482.

(4) 小寺重孝 (1974)：私信

(5) Kawanishi, Y., Cho, F. and Honjo, S.(1973) : Normal values of the serum protein fraction in cynomolgus monkeys used as experimental animals. Japan. J. Med. Sci. Biol., 26, 249260.

\section{5. 入手実験に際して特に注意すべき諸点}

\section{藤 原徹（国立予研）}

サルを使用しての研究分野とその使用頭数の増大は近 年著るしいが，乙のことは，実験用サルの質と量との低 下をまねくに至っている。それ故, 如何にサルを無䭾な く有効に使用するかということが, 当面の課題となって きている。このような観点から，今回はまず実験用サル の入手から実験後の処理にいたる一連の過程における注 意点を具体的に述へ，次いでサルを使用しての実験に対 する基本的な考え方を問題の摘出と提案という形で述べ る。

発注から入手まで：輸入野生サルの発注に際して注意 すべき点として，実験開始予定時より約 4 力月前に発注 すること, 実験に必要な頭数の約 $30 \%$ 増を発注すること, 特殊な規格を附して発注しても満たされないてとが多い ことなどの点が挙げられる。

検疫について：欧米では監督官朾の指導のもとに関係 法律に基づいて，少なくとも 3 力月の検疫をおこなって いる例が多いが，わが国では未だ厚生省がその検疫問題 を検討している段階である。将来の検疫体制として, 輸 入港での観察ならび情報収集配布, 指定検疫施設で 9 週 間以上の検疫, 実験施設での実験前健康管理という一連 のシステムを提案したい。検疫にあたっては, サルはヒ トに対して危険な各種病原体を保有しているという前提 で, 防護衣類の着用を厳守し, 適切な消毒滅菌を履行す ることが，第一に必要である。

実験動物技術者の業務内容抢よび養成：業務内容は日 常管理業務, 実験手技, 繁殖業務と大別できる。これら はいずれもサルであるが故の特殊な面をもっている。技 術者はサルの取扱いに不慣れな実験者に協力し，また代 って実験を㧍てなわなくてはならないことああるので， サル専門の技術者の一貫したかなり長期間の教育と訓練 ができる教育機関の設置が望まれる。さらに，日常管理 と検疫とに主体を掞いた 3 力月実習コース, 日常管理, 検疫に繁殖技術を加えた 6 力月実習コースを試案として 呈示したい。

飼育管理室, 飼育ケージを含む器具器材：飼育室は充 分広いこと，逃亡を防げること，消毒洗滌が容易である ことを主眼に設計する。管理舎は污染区域と清浄区域と を明確にして，両区域をシャワー，更衣，消毒などでは っきり境界づけることが大切である。飼育ケージやその 他の器具器材は, 堅审なとと, 消毒洗滌が容易な単純構 造であることなどが大切である。 
材料採取, 採取材料の処理, 屍体污物の処理時の注意 点：それぞれの場合に，サル類のすべての材料，㡾体， 污物はヒトにとって危険であるという前提で取扱われる ことが肝要である。そして実験者 1 人 1 人が危険防止に 責任があることを自覚する必要がある。

次に, サルを使用しての実験に対する基本的な考え方 を述へる。野生サルを実験に供していることから生ずる 問題点の根本的解決は, サルを自家生産し実験に供して いくという近い将来の方策によらざるをえないとして あ, 現実的な態度としては, サルの使用についての考え 方を整理し，適切な方法で実験がなされるようにしてい くべきであろう。

第 1 は, サルを使用しての実験に至るまでの段階は如 何にあるべきかという点である。サルを使用しての実験 に臨む前に，既に実験動物としての確立され特性む明ら かになっている他種動物によっていくつかの現象や法則 を把握整理しておくべきであると考える。このことは， 無䭾にサルを使わないという意味ばかりでなく，サルと いう複雑で高度に発達した動物の系での実験は, 他の比 較的単純な実験系での解析をふまえたうえでおこなうこ とによって, その結果の解析がー一層容易に系統づけられ るのではないかという考えに基づいている。

第 2 は, サルがその実験の目的に適った動物であるか どうかをよく考えたうえで実験に供すべきであるという ことである。すでにサルの有用性についての評価は高い が，一方では，サルを使用しなくても他種動物ですむと いう場合がある。しかしここで問題となるのは，全般的 にはサルの生物学的特性に未解明の点が極めて多いとい うことである。そのために，サル自身についての各研究 分野の積極的推進と研究体制の確立が望まれる。そして どのサル種が目的とするヒトでの問題を解明するために 至適であるかということを見出すためにあ，いろいろな サル種での実験を積重ねる必要があるというととを念頭 におかねばならない。

第 3 は, サルの持っている個体差の問題と少数例実験 を余儀なくされるということからデータ解析が難かしい という問題がある。野生サルは, 遺伝体質が不定である ばかりでなく，生体の反応に関与するさまざまな既知未 知の変動要因を内在させていることが多く，てのことが 個体差を生ずる主要な原因となっている。したがって, 長期間の実験室条件下飼育による生理的安定化, 個体毎 のベースラインデータの採取, 再現性確認のための実験 のくりかえしなどが必要である。

第 4 は，各実験施設での実状を考慮した実験実施上の ルールの確立とその順守である。規約の作製にあたって は, 無原則的になってはならないこと, 危険なものを明 確にすることと危険を拡大させないための具体策を中心
に，関係者の合意と理解のあとに立案すべきである。

最後に，昨年施行された“動物の保護および管理に関 する法律”にふれる。この法律に規定されている動物の 健康および安全についての所有者責任と他人への危害防 止についての所有者責任および飼育規準作製の必要性な どの考え方は，そのまま上述の実験用サルの入手，検 疫, 実験に対する考え方と軌を一にしていると考えられ る。また，乙の法律に準拠して，実験用サルのかかえて いる矛盾点を解決する契機がえられるならば，ての法律 はサルでの動物実験の質的向上に役立つということがい えよう。

$$
\begin{array}{lll}
\text { ま } & \text { め } \\
& \text { 本 } \text { 庄 重 男 (国立予研) } \\
& \text { 田 } \text { 中 利 男 (日本モンキーセンター) }
\end{array}
$$

はじめに：

本シンポジウムは, 全体のスケジュールとの関係上, 2 日間にまたがり，しかす第 1 部は途中の演題から翌日 まわしになるという大層変則的な運営にならざるを得な かったにあかかわらず, 終始 200 名を越える参集者を得 て, 活発, 盛大に進行した。乙れは, 各報告者, 座長の 諸先生はもとより, 会の運営に当られた役員諸氏, 参集 の会員各位の御協力の賜物であり, 司会者として深く感 謝する次第である。

さて，予稿集の嘪頭にあ記したように，本シンポジウ ムは, 今日の発展した各個別領域の研 究 水準に立脚し て，上トのモデルとしてのサル類つ有効性と限界を，で きるだけ総合的にとらえ，つぎのステップでサルをどう 役立たせるかということについての見通しや行動の足が かりを得ることを意図して企画されたものであった。そ のために, 第 1 部では, 各個別領域の内面から主題が論 じられると同時に，第 2 部の報告者への問題提起むおと なわれた。第 2 部は, サル自身を対象としている研究者 や主としてサル類を実験動物化するという立場で仕事を 進めている方々によっておてなわれ，現段階で実験に供 しているサル類の持つ基本的問題点を，“有効性と限界” に関係するいわば外的な諸条件として捉えた議論が展開 され，第 1 部の方々の問題提起にあ応答するという形が とられた。

個々の演者の報告要旨は別に記載されたとうりである ので, ここでは, 司会者のまとめとして, 第 1 部, 第 2 部については質問事項, 追加意見の主なものを列記し, 第 3 部（総合討論）については質疑と応答のほぼ総てを 私どあの文責において要約する次第である。 第 1 部:

大沢氏の講演に対しては, 武田中研の島本氏より, hypothalamic releasing hormone に関してサル類を用 
いた実験を組むことにより，上トの行動や感情の多様な 発現とホルモンとの関係などが明らかになるあのと期待 される旨の追加発言があった。また, 東北大医の渡辺氏 より, Steroid hormone の日内変動のメカニズムにつ いての質問があった。

松島氏の講演に対しては, 実中研の田中氏より, サル を毒性試験に用いる場合，ラットやイ邓よりあ有用であ る面および不利な面, とくに思いがけない事故について 臨床病理学的立場からみた意見が披歴された。

山内氏の講演に対しては, 本会理事長田嶋氏より上上 の肝炎とサルの肝炎との関係および，マールブルグウイ ルス研究のその後の経過等について質問があった。

畠山氏の講演に関連して, 岩手医大若生氏より, アメ リカの霊長類実験施設および実験状況についての簡単な 追加があり, 獣医学者と医学者との連携の見事さが特に 強調された。と同時に, わが国であとの分野を強力に推 進させる必要のああることが力説された。

真野氏の講演に対しては, 予研本庄より, 神経生理学 領域での新世界サルの利用状況もしくは有効性について の質問があった。

糸魚川氏の講演に対しては, 京大霊長研登倉氏より, 空調された飼育室内での毛抜きの behavior をどう解釈 すべきかとの質問があった。

第 2 部:

水原氏の講演に関連して, リサーチプライメイツジャ パンの川西氏より, 最近㧍ける日・米・英 3 国のサル 輸入数の変遷状況を比較した追加があり, 米・英ではこ こ $3 ， 4$ 年来かなり輸入規制がおこなわれているのに, ひとり日本だけが上昇傾向を示している事実のあつ意味 について, 自然保護および医学実験目的での無䭾のない 利用という観点から重大な警鐘が打たれた。

和氏の講演注しては，予研高阪氏より，治療可能な 種類の異常に際しては, 無䭾なく利用するという意味 で, 検疫期間中に治療処置を講ずべきだという点と, 無 症状の赤峲菌保菌サルがかなり多いととを無視しては危 険であるという点が指摘された。また, 三共中研の阿久 沢氏より, ノーマルな状態の定義, 輸入野生サルがケー ジ飼育条件へ順応するまでに要する時間, サルの健康の 指標として最適と思われる血液性状, 等について質問が 発せられた。

登倉氏の講演に対しては，鹿児島大医の山内氏より， 産熱量の測定条件および thermoneutral zone で飼育す るマウスでは繁殖能の低下が認められるが， サルの場合 はどうか，との質問があった。また，中外製薬綜研の辻 氏より，新入荷サルを人工飼㕕下に置く場 合，たとえ ば，温度条件の設定はどういうステップでおこなえばよ いか，との質問があり，乙の点に関連して予研長氏より
予研での方法と経験が追加説明された。

長氏の講演に対しては, 残留農薬研の高橋氏より, 演 者が述べたサル繁殖コロニーでの近交退化の予想につい て質問があった。

藤原氏の講演に関連して, 東大医科研鈴木潔氏より, 検疫抢よび健康管理期間が 9 週間あるいは 12 週間とされ る生理学的根拠や感染疫学的根拠について質問がおてな われた。ついで, 京大霊長研松林氏より, 消毒薬の使用 之净化槽の効力との関係について議論が提起され, 日本 モンキーセンターの和氏, 実中研の谷岡氏, 都心身障害 センターの小島氏等より，それぞれの経験にもとづく見 解が述べられた。また，理研の鈴木氏より，サル類を扱 う人に打ける vaccination の必要性についての問題提起 があった。

第 3 部(総合討論)：

総合討論は, 第 1 部, 第 2 部の報告, 質疑を踏まえて おこなわれた。

まず，予研藤原氏より東大医大沢氏に対し，妊娠婦人 の血中コレステロール值は上昇するのに娃娠マカカ属立 ルではむしろ低下するという現象は，妊娠中のステロイ ド合成機序がヒトとマカカ属サルとで差があるととと関 連ありと考えてよいか，との質問があり，大沢氏より， 妊娠中の性ホルモンの動態がヒトとサルとでは極めて異 っているので, そのようは差があってあよいと考えられ る旨解答され, この点でマカカ属サルは上トのモデルと しては不適当であると認められた。

ついで都立老人研の奥木氏より，予研長氏に対し， サ ルの生産コスト, 一生の生産可能仔数, 年令推定法, 寿 命等につき質問があった。長氏によれば，生産コストに ついては未だ計算作業をしていないので不明である。こ れ対し, 日本モンキーセンタ一の小寺氏からは, 生産 コストは非常に高くなると考えるべきだが，サル資源の 衰退という現実を前にして, 野生サルは使わないとの観 点からすれば, コストは問題にならない, との意見が追 加された。

ところで, 生産コストに限らず, 野生サルの購人費や 飼育費等が高価であることが， サルでの実験遂行の制限

因子になっているという意見を第 1 部で真野氏が開陳さ れたことと関連し，座長は「米国の LEMSIP (Laboratory for Experimental Medicine and Surgery in Primates）の Moor-Jankowski 博士が, cost-effectiveness という概念にもとづいて考えると，サル類での 実験は決して高価ではない」という意見を表明している ことを紹介し，乙のような考え方について真野氏にコメ ントを求めた。真野氏からは, “神経生理学の分野でサ ルは, 数頭でひとつの論文がまとまるような種類の慢性 実験で主に使われている。40頭から50頭も使わねばなら 
急性実験では，その成果が如何に有益であると期待さ れてあ，今日のわが国の研究費等の実情では断念せざる を得ない。確かに目的によっては如何に高価でも多数の サルを急性実験に使わねばならぬ場合があるが，それを 実行できる研究室は国際的にみてあかなり限られている と思われる”旨の返答があった。このととと関連して, 名古屋市大医の杉浦氏より，LEMSIP では数年前， サ ル 1 頭の維持費が 1 日 2 ドルであったことが紹介される ととあに，そこでの方式にならい，日本であ 1 頭のサル を多方面の研究者が有効に使うととを保障するようなシ ステムが確立されることを強く期待する旨の発言があっ た。ちなみに, LEMSIP では, 関連する地域の大学, 研 究所の研究者に研究課題を提出させ, それらを arrange して，1頭のサルでいくつかの実験をおてなえるように 組んでいる。たとえば，1 頭の成熟雌について内分泌学 的研究, それが妊娠したら妊娠時の変化の研究, 生れて きた仔ザルについては周生期生理の研究等々と，それぞ れの研究者に計画的に材料を提供する。各研究者から は, その実験内容に応じて費用を徵集し, 維持費の一部 に当てている。

ついで議論は検疫の問題に移った。まず，予研藤原氏 が提示した検疫システム案との関連で，城西大五嶋氏よ り新設の単科大学で実験用サルの検疫施設を確保し, 要 員を充当することの困難さが説明され，検疫済の安心し て使えるサルの供給体制が是非必要である旨の発言があ った。ついで，農林省動物医薬品検査所窪道氏が，藤原 案を補強する形で, 輸入サルの検疫は公衆衛生的見地か ら国の水準で考慮すべき旨の意見を表明した。また，京 大霊長研松林氏より，外国産サルが日本到着後受取施設 に運ばれるまでの輸送途上の污染問題も，日常的に運送 会社などを啓蒙するととにより充分注意せねばならぬ旨 の指摘があり，同時に実験動物研究会としてもこの種の 問題を考慮し，適切な行動をとるようにとの要望がなさ れた。この点に関し，座長より予研でのやり方が紹介さ れた。すなわち, 予研ではサル輸送車が到着した場合, 運転手にはサルケージに一切触れさせず, 受取り作業全 部を防護衣類を着用した予研職員が実施し, 終了後, 卜 ラック荷台に消毒薬を充分散布して帰路につかせる。

自然発生疾病の問題では, 肺ダ二の寄生がアカゲザル ではカニクイザルでよりあ多いということの理由につい て, 阪大微研(観音寺)井戸坂氏より質問があり，乙れに 対し, 中外製薬綜研福井氏より, その種の事実を示す報 告は知らないが, 野生サルを捕獲して使う状態が続く限 り, 今後充分調査, 研究する必要があると考える旨の意 見が述べられた。

生産方式との関連では, 農林省動薬研の寉道氏より, 屋外方式の場合, 二ホンザルでは排他性が強いため繁殖
効率が低いことはないか，また，乳仔を早期に離乳させ ると発情回帰が早くなるか，といった質問があり，モン キーセンターの和氏より，二ホンザルは排他性が強いよ うに一般に言われているが, 事実は, 他種のマカカ属告 ルに比べてとくに著しく強いということでもなく, 群れ 作りの段階でよく選別すれば，排他性の故に繁殖効率が 低下するようなことはないと考えられる。ニホンザルの 場合, 問題はむしろ, 一定の繁殖季節があり, 年間を通 じて仔ザルを得ることはできない，という点である。ま た，早期離乳をすれば発情回帰が早くなるという事実は 認められている，との解答があった。また，中外製薬総 研塩田氏より，サルを大事にとり扱うという立場で考え た場合，生産の場で，育成期間中にトレーニングをする ことにより実験に生かされるととがあるか否かという問 いが発せられ，予研長氏より，実験術技の種類によって は，野生サルよりあ育成サルでのトレーニングは容易で あるので，活用できると言えよう（たとえば，体重測 定胵垢材取等）との返答があった。さらに，実中研高橋 三郎氏からは，実中研メディカルラボでの豊富な経験に あとづき，薬剤投与を順番に簡単におこなえるようにす るトレーニングなどは可能であり，そのことによって繁 殖行動をふくむサル自身の行動に異常があたらされるよ うな結果はない, との追加発言があった。

つぎに，サル類保護と利用という問題に関連して， 「有用なサル類を適切に実験動物化し，生産システムを 確立し，どしどし使うべきだという実験動物の側からの 主張があるが，モンキーセンターの水原氏は生態学者の 立場でこれをどう考えるか」との問いかけが座長よりな された。水原氏によれば，“保護と繁殖とを混同する と，サル類の保護はできなくなる。original habitatで の自然の生活の保護には，繁殖を目的とする手を加える べきではない。繁殖用には人工的なコロニーを作るべき であり，ての意味で実験動物学の主張は納得できる。し かし, 餌付けされた自然群を生産繁殖の能率を上げるた めのものとして利用してきた過去の誤ちは, 今日では改 められねばならない”旨の見解が表明された。この問題 と関連して, 本会田嶋理事長より, サル類の実験動物化 を急ぐべしとの座長の意見には全面的に賛成であり，そ れは信頼のおける成績を得るために是非必要である, と の見解が述べられるとともに，一般的な実験動物を使っ たのちヒトに外扱する前にサル類を使いたいとの希望を 多くの分野で持たれるであろうが，それは，サル類の有 効性と限界を知るうえでも重要なととである。ただし， 現在では捕獲野生動物であるという認識を正しく持って 検疫処置を厳重にして危険のないようにとり扱うことが 必要である, との指摘が追加された。

最後に, 東大医科研の鈴木潔より, アカゲザルでの胃 
癌誘発実験の経験から, 有効性は胃癌ができてみて始め て論ずるととができるし，限界も実験をおてなってみな ければ判らない。要するに, 有効性と限界を云々するた めには, 予備実験と予備知識が必要と考えている旨の発 言があった。

むすび：

およそ以上のように進行した本シンポジゥムは, 果し て当初の目標とした地点に辿りついたであろうか。時間 的制約もあり, 充分に議論が展開されなかったきらいも あるが，2 日間を通じて会場で共通して得られた認識 は，およそつぎの 3 点に要約されるように思われる。

第 1 に，ヒトのモデルとしてのサル類の有効性につい ては冷静な判断が必要であるが，このことは，裏を返せ ば，その限界についての妥当な認知が必要だということ である。そして，その限界をどう乗り越えるかという問 題は, むろん各個別領域の研究者一人一人の創意工夫に ゆだねられてはいるが, ‘同時に, 各領域相互の交流, 協 力があるならば, より適確に解決される端緒が得られる であろうということ。

第 2 に，とにかくわが国の現段階では，未だ，有効性 を信じて熱心に研究を進めているというのが大 勢であ り, 限界についての正確な認識は今後の進展如何による ということ。そして, いろいろなサル種について, さま
ざまな角度からその生物学的特性を明らかにして行く研 究が基本に据えられて始めて “有効性と限界”を真に明 らかにすることができるのであり，まさにこの意味にお いて, サル自身の生物学に, あっと多くの関心が寄せら れねばならない, ということ。

第 3 に，資源の衰退という事態を前にし，同時に， 上 上に対して危険ではなく，質の良いサルを供用するとい う実験動物学本来の道筋加ら考えるとき, 無䭾なくサル を使うとの基本概念に立脚しつつ, 検疫・供給体制, 共 同利用体制，生産体制等を関係者の協力により一日も早 くわが国でも確立することが必要である，ということ。

むし，実験用サル類つ使用数は人間社会における人命 尊重の度合の尺度となり得ると考えることが許されるな らば, 私どあ日本人の生命は, アメリカ人の生命の約 10 分の 1 程度にしか尊重されていないという計算になる。 この意味からすれば，わが国では，上トの代用としてサ ル類を一層多数活用すべきだとの主張は正当であろう。 そして，本シンポジゥムで語られたように，各専門領域 の枠を超えた研究協力を心掛け，検疫・生産・供給をふ くめた総合的な研究推進の体制を早急に作り上げること を, 関係者一同が努力しない限り, この分野での欧米之 の隔差は拡がるばかりであろう。 